\title{
Chapter 8 SDG 8: Decent Work and Economic Growth - Potential Impacts on Forests and Forest-Dependent Livelihoods
}

Dietmar Stoian*, Iliana Monterroso and Dean Current

\section{Key Points}

- Diverse combinations of predominant development paradigms lead to differentiated SDG 8 target prioritisations, with mixed impacts on forests and people.

- Significant trade-offs are expected for countries focused on the growth of agriculture, energy and mining: the decoupling of economic growth from forest-related environmental degradation will be a major challenge. Global trade-offs are anticipated on climate change.

- Synergy potentials exist where growth strategies and associated policies explicitly target the forest sector with a view on tree plantations, timber and non-timber forest products (NTFPs) from natural forests, ecotourism and payments for environmental services.

- Improvements in the enabling environment can help minimise trade-offs and maximise synergies by reconciling government policies and private sustainability standards, formalising community stewardship of tropical forests, addressing the informality prevalent in forest product value chains and providing specific incentives for youth to become involved in forest-based economic activities.

- Advancing decent work in the forest sector requires addressing gender, ethnicity and other social differentiation factors, as well as mobility aspects and labour safety.

- Alternative, more integrated measurements of economic growth and decent work are needed, accounting for broader environmental and social impacts.

\footnotetext{
* Lead author.
} 


\subsection{Introduction}

\subsubsection{Conceptual Foundations of Decent Work and Economic Growth}

Since the early twentieth century, the core of prevalent socio-economic and political systems has been economic growth. This has fundamentally and irreversibly reshaped societies and the entire planet (Schmelzer 2017). In the aftermath of World War II, emerging theories and paradigms for developing non-industrialised countries in the Global South were largely based on the premise of economic growth (e.g. modernisation theory), if not overtly labelled as such (economic growth theory).

The concept of decent work, however, only appeared at the end of the twentieth century. Tensions between economic relationships and their social context arose in the late nineteenth century (Rodgers 2007), addressed by the emerging trade unions. Yet it was not until 1999 that the International Labour Organization (ILO) launched the concept of decent work. Its emergence reflected new development theories and paradigms that sought to overcome the limitations of the modernisation and economic growth theories and associated policies. Nurtured by Maslow's theory of human motivation, the 1970s laid the foundation for a development theory of human needs (Max-Neef et al. 1992). The resulting basic-needs paradigm reformed development programmes in the 1980s by integrating social indicators into the measurement of economic growth. Environmental indicators were added in the 1990s as the sustainable development paradigm emerged in response to global environmental degradation (Lélé 1991).

Policies and strategies based on diverse development theories and paradigms have varied effects on forests and forest-dependent livelihoods. This chapter introduces an analytical framework illustrating the evolution of such theories and paradigms, the contextual conditions shaped by them and the principal drivers determining the impact of SDG 8 implementation on forests and people dependent on them (Section 8.2). We then present key actors and stakeholders in the forest and other natural resource sectors and the latter's contributions to national economies. The subsequent assessment of anticipated impacts (Section 8.3) addresses forest-based economic growth and decent work in forest product value chains (FPVC) from livelihoods, enterprise and conservation perspectives. Synergies and trade-offs are then discussed, within SDG 8 implementation, and with other SDGs (Section 8.4). We conclude with an outlook on how overarching development paradigms lead to varying prioritisations of SDG 8 targets, and how decoupling economic growth from forest-related degradation will continue to be a challenge for countries seeking economic growth in natural resource sectors other than the forest sector (Section 8.5). 


\subsubsection{Indicators for Decent Work and Economic Growth}

The SDG 8 targets and indicators reflect a firm grounding in economic growth paradigms and, to some extent, the paradigmatic evolution to a more integrated set of indicators, including social and environmental aspects (Table 8.1).

\section{Table 8.1 SDG 8 targets and indicators}

\begin{tabular}{|c|c|}
\hline Targets & Indicators \\
\hline $\begin{array}{l}\text { 8.1 Sustained per capita economic } \\
\text { growth - min. } 7 \% \text { GDP growth per } \\
\text { annum in least developed countries }\end{array}$ & $\begin{array}{l}\text { 8.1.1 Annual growth rate of } \\
\text { real GDP/capita }\end{array}$ \\
\hline $\begin{array}{l}\text { 8.2 Higher levels of economic } \\
\text { productivity }\end{array}$ & $\begin{array}{l}\text { 8.2.1 Annual growth rate of real } \\
\text { GDP/employed person }\end{array}$ \\
\hline $\begin{array}{l}\text { 8.3 Development-oriented policies } \\
\text { for formalized micro-, small- and } \\
\text { medium-sized enterprises }\end{array}$ & $\begin{array}{l}\text { 8.3.1 Proportion of informal } \\
\text { employment in non-agriculture } \\
\text { employment (by sex) }\end{array}$ \\
\hline $\begin{array}{l}\text { 8.4 Global resource efficiency in } \\
\text { consumption and production and } \\
\text { decoupling economic growth from } \\
\text { environmental degradation }\end{array}$ & $\begin{array}{l}\text { 8.4.1 Material footprint (per capita } \\
\text { and GDP) } \\
\text { 8.4.2 Domestic material consumption } \\
\text { (per capita and GDP) }\end{array}$ \\
\hline $\begin{array}{l}\text { 8.5 Full and productive employment, } \\
\text { decent work for all women and } \\
\text { men, and equal pay for work of } \\
\text { equal value }\end{array}$ & $\begin{array}{l}\text { 8.5.1 Average hourly earnings of } \\
\text { female and male employees (by } \\
\text { occupation, age and persons } \\
\text { with disabilities) } \\
\text { 8.5.2 Unemployment rate (by sex, age } \\
\text { and persons with disabilities) }\end{array}$ \\
\hline $\begin{array}{l}\text { 8.6 By } 2020, \text { proportion of youth not in } \\
\text { employment, education or training } \\
\text { substantially reduced }\end{array}$ & $\begin{array}{l}\text { 8.6.1 Proportion of youth not in } \\
\text { education, employment or } \\
\text { training }\end{array}$ \\
\hline $\begin{array}{l}\text { 8.7 Forced labour, modern slavery, } \\
\text { human trafficking and worst forms } \\
\text { of child labour eradicated (by } 2025 \\
\text { child labour in all its forms) }\end{array}$ & $\begin{array}{l}\text { 8.7.1 Proportion and number of } \\
\text { children engaged in child labour } \\
\text { (by sex and age) }\end{array}$ \\
\hline $\begin{array}{l}\text { 8.8 Labour rights protected and safe } \\
\text { and secure working environments } \\
\text { for all workers }\end{array}$ & $\begin{array}{l}\text { 8.8.1 Frequency rates of occupational } \\
\text { injuries (by sex and migrant status) } \\
\text { 8.8.2 National compliance of labour } \\
\text { rights (freedom of association } \\
\text { and collective bargaining, by sex } \\
\text { and migrant status) }\end{array}$ \\
\hline
\end{tabular}




\begin{tabular}{|c|c|}
\hline Targets & Indicators \\
\hline $\begin{array}{l}\text { 8.9 Policies for sustainable tourism (job } \\
\text { creation, promotion of local culture } \\
\text { and products) }\end{array}$ & $\begin{array}{l}\text { 8.9.1 Tourism direct GDP (proportion } \\
\text { of total GDP and growth rate) } \\
\text { 8.9.2 Number of jobs in tourism } \\
\text { industries (proportion of total } \\
\text { jobs and growth rate, by sex) }\end{array}$ \\
\hline $\begin{array}{l}\text { 8.10 Domestic financial institutions } \\
\text { strengthened (enhanced access to } \\
\text { banking, insurance and financial } \\
\text { services) }\end{array}$ & $\begin{array}{l}\text { 8.10.1 Number of commercial bank } \\
\text { branches and ATMs } \\
\text { (per } 100 \text { 000 adults) } \\
\text { 8.10.2 Proportion of adults with an } \\
\text { account at a bank or other } \\
\text { financial institution or with a } \\
\text { mobile-money-service provider }\end{array}$ \\
\hline $\begin{array}{l}\text { 8.A Aid for Trade support for developing } \\
\text { countries increased, in particular for } \\
\text { least developed countries }\end{array}$ & $\begin{array}{l}\text { 8.A.1 Aid for Trade commitments and } \\
\text { disbursements }\end{array}$ \\
\hline $\begin{array}{l}\text { 8.B By 2020, a global strategy for youth } \\
\text { employment and the Global Jobs } \\
\text { Pact of ILO implemented }\end{array}$ & $\begin{array}{l}\text { 8.B.1 Total government spending } \\
\text { in social protection and } \\
\text { employment programmes } \\
\text { (proportion of the national } \\
\text { budgets and GDP) }\end{array}$ \\
\hline
\end{tabular}

Note: Targets are for 2030 unless stated otherwise.

Source: Adapted from UN (2019)

The SDG 8 targets and indicators align with the ILO (2018a) framework on the measurement of decent work, which is closely linked to four strategic pillars: (1) international labour standards and fundamental principles and rights at work, (2) employment creation, (3) social protection and (4) social dialogue and tripartism.

\subsection{Framework for Analyses}

\subsubsection{Development Paradigms Driving Policies, Institutions and Markets}

How 'less developed' countries can follow the pathway of 'developed' countries, or how they can be 'modernised', has been disputed by social scientists for more than a century. This debate has influenced development thinking 
and policymaking around the globe. In response to challenges and opportunities facing the developing world in the postcolonial era, the modernisation paradigm was developed in the 1950s. Advocates such as Rostow (1959) assumed a universal evolutionary path from traditional societies to the age of high mass consumption. The underlying assumption of relatively uniform, linear modernisation pathways was soon criticised. It was argued that the societal boundaries, political and economic institutions, and the social distribution of power underlying the absence of 'modern' societies had to be identified and solutions be developed accordingly (Tipps 1973).

Despite such criticism, the modernisation paradigm has strongly influenced development policies and strategies worldwide, with economic growth at its core and a simplistic equation: industrial transformation equals economic growth, which, in turn, allows poorer countries to catch up with industrialised countries. Eventually, economic growth would generate broader societal wealth through trickle-down effects (Thornton et al. 1978).

The modernisation and growth paradigms have had a strong imprint on tropical forests and, to some extent, temperate ones too. Starting in the 1950s, governments have increasingly treated forests as a natural capital reserve to be exploited for industrial transformation - initially through log sales, and progressively through value-added products. Processes of forestbased industrialisation occurred in several waves across forest-rich regions along the tropical belt: West Africa (1950s-70s), Southeast Asia (1960s-80s) and, more recently, the Congo and Amazon basins. However, the prevalent view of development as a purely economic phenomenon securing jobs and economic opportunities for the masses soon turned out to be a myth (Arndt 1983). When the waves started to ebb in the late 1970s it became evident that industrialisation based on natural resource processing is likely to perpetuate the pattern of dualism and inequality present in typical resourcerich countries, rather than leading to efficient growth, employment creation, greater equity and economic independence (Roemer 1979). The model of a 'dual economy' (Lewis 1954), which assumes that the agricultural sector (including forestry) generates the capital necessary for take-off towards industrialisation before becoming redundant, was shown to ignore the positive link between growth in industry and agricultural growth (Verner and Blunch 1999).

Over the past decades, new theories and models have emerged that provide a more nuanced picture of development processes: 'basic needs' (1970s), 'sustainable development' (early 1990s), 'sustainable livelihoods' and 'green growth' (both late 1990s). These are reflected in the Millennium Development Goals (2000), followed by the Sustainable Development Goals (2015). Lately, it has been suggested that alternative measures to GDP are needed, such as 
the Genuine Progress Indicator (GPI), ${ }^{1}$ World Values Survey (WVS), ${ }^{2}$ Happy Planet Index (HPI) ${ }^{3}$ and Better Life Index ${ }^{4}$ (Costanza et al. 2014).

Despite these conceptual advances, many factors that have long been driving economic policy in relation to natural resources are still at play. While protected areas in tropical countries have been expanded and forest ecosystem services figure more prominently on political agendas, development policies, institutions and markets continue to be largely driven by modernisation and economic growth paradigms. This prompts the question of what effects these paradigms have on the natural resource base of tropical countries and economic activities based on them - a question this chapter addresses with a view on forests and FPVC.

\subsubsection{Analytical Framework}

Our analytical framework for assessing the potential impacts of SDG 8 on forests and forest-dependent livelihoods has been derived from our own reflection, insight and conceptualisation. It accounts for the development theories and paradigms outlined in the previous section as well as contextual conditions that determine the impact of principal drivers:

- political-legal framework: principal policies geared towards forest, agriculture, energy, mining, tourism sectors;

- institutional support environment: technical and financial assistance by government agencies, non-governmental organisations (NGOs), the private sector;

- macroeconomic conditions: composition and evolution of GDP, formal and informal employment, standard of living;

- market forces: supply-demand patterns in the forest, agriculture, energy, mining, tourism sectors;

- status of the forest resource base: forest cover, degradation and deforestation; institutional arrangements for protecting forests;

- cultural contexts: importance of forests at societal, communal levels.

\footnotetext{
${ }^{1}$ In addition to GDP measurement, the GPI considers the cost of the negative effects related to economic activity (e.g. resource depletion).

${ }^{2}$ Based on nationally representative surveys in almost 100 countries, the WVS provides crossnational time series on human beliefs and values.

${ }^{3}$ Drawing on existing metrics, the HPI accounts for well-being, life expectancy, inequality of outcomes and ecological footprint.

${ }^{4}$ OECD's Better Life Index measures 11 parameters (income, jobs, housing, health, access to services, environment, education, safety, civic engagement and governance, community and life satisfaction).
} 
The analytical framework also accounts for interactions with policies and trends in relation to other natural resource sectors (agriculture, energy, mining) and associated services (tourism, provision of ecosystem services).

Within the forest sector, our assessment focuses on the following stakeholders:

- national and local governments

- international and local NGOs

- multinational and national companies

- corporate associations

- small and medium enterprises

- Indigenous and non-Indigenous groups dependent on forests

We assess the impact of SDG 8 on the forest sector with a view on the forest industry, forest-dependent people and the forest resource base (Figure 8.1).

\subsubsection{Key Actors and Stakeholders}

Our analytical framework distinguishes between key actors influencing the design and implementation of policies and strategies for achieving SDG 8 on the one hand, and forest-sector stakeholders affected by these policies

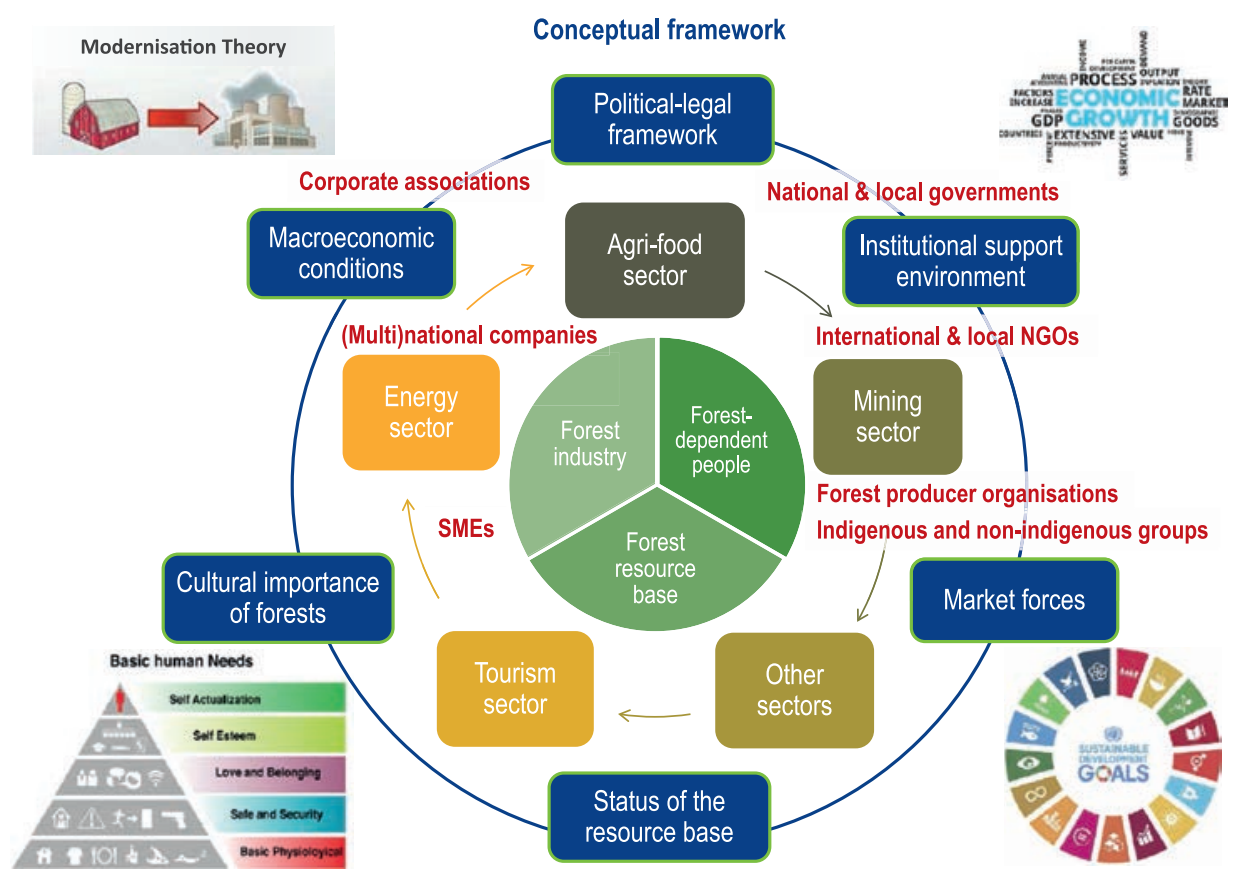

Figure 8.1 Analytical framework for assessing the impact of SDG 8 on forests and forest-dependent people. 
and strategies on the other. Key actors in the political arena are national and local governments, with their legislative, regulatory and executive powers varying according to governance structures and the degree of decentralisation. Principal stakeholders are forest users, including the forest industry and forest-dependent people. Further stakeholders are civil society organisations, ranging from local and international NGOs to corporate associations, and society as a whole. Depending on their role inside or outside of FPVC and their influence on political-legal and regulatory decisions, given groups may be both key actors and stakeholders. Their interactions are complex, as are the forest-tenure arrangements underlying interactions. In our assessment of statutory forest tenure (Table 8.2) and subsequent analyses, we focus on the top 10 countries with largest forest area (Top10-LFA) which account for 50 per cent of the global forest area and represent both industrialised (Australia, Canada, Russian Federation, United States) and emerging or developing economies (Brazil, China, DR Congo, India, Indonesia, Peru).

Table 8.2 reflects that, across the 58 countries studied, 72 per cent of the forest area in 2017 was publicly administered, while an increasing portion is owned by Indigenous peoples and local communities (13 per cent) or has been designated to them for their use (2.3 per cent). Forest tenure varies significantly across the Top10-LFA, ranging from countries where most of the forests are publicly owned and controlled (Russian Federation, DR Congo, India, Indonesia) to countries with incipient (Canada), moderate (Australia, Peru) or strong (Brazil, China) devolution of forest tenure and rights to local communities. In Australia, Brazil, Canada, India and the United States, significant portions of forests are owned by individuals and firms and, across the 58 countries studied, 12 per cent of the forest area was privately owned in 2017 (RRI 2018). On a global scale, the area of publicly owned forests for which management rights have been granted to private companies under concessionary or licensing agreements has increased from 6 per cent in 1990 to 14 per cent in 2010, as has the area of forests within protected areas which reached 16 per cent of global forest area in 2015 (FAO 2016). Not reflected in these figures are overlapping claims between publicly or privately owned forests and those under local customary rights.

\section{NATIONAL AND LOCAL GOVERNMENTS}

National and local governments play a central role in the future of forests as representatives of publicly owned forests and as policymakers and regulators. At the international level, coordinated government efforts contribute to meeting global (e.g. Bonn Challenge) and regional (e.g. 20 x 20 Initiative) goals. At the country level, the political-legal and regulatory frameworks reflect the role of forests in national development strategies, both as regards the forest sector and vis-à-vis other sectors. The principal management objective of the 
Table 8.2 Statutory forest tenure (millions of ha) in the top 10 countries with largest forest area and the 58 countries included in the study of RRI (2018) which account for 50\% and $86 \%$ of the global forest area, respectively, 2002 and 2017

\begin{tabular}{|c|c|c|c|c|c|c|c|c|}
\hline & \multicolumn{2}{|c|}{$\begin{array}{l}\text { Government } \\
\text { administered }\end{array}$} & \multicolumn{2}{|c|}{$\begin{array}{l}\text { Designated for } \\
\text { indigenous peoples and } \\
\text { local communities }\end{array}$} & \multicolumn{2}{|c|}{$\begin{array}{l}\text { Owned by indigenous } \\
\text { peoples and local } \\
\text { communities }\end{array}$} & \multicolumn{2}{|c|}{$\begin{array}{l}\text { Privately owned by } \\
\text { individuals and firms }\end{array}$} \\
\hline & 2002 & 2017 & 2002 & 2017 & 2002 & 2017 & 2002 & 2017 \\
\hline Australia & 94.0 & 83.3 & 0.0 & 9.1 & 20.9 & 12.1 & 14.0 & 20.2 \\
\hline Brazil & 341.0 & 238.4 & 10.7 & 40.4 & 75.3 & 118.1 & 94.3 & 99.9 \\
\hline Canada & 319.3 & 318.3 & 0.2 & 0.3 & 6.6 & 6.8 & 21.7 & 21.6 \\
\hline China & 76.1 & 75.2 & - & - & 103.1 & 124.3 & - & - \\
\hline DR Congo & 157.3 & 152.4 & - & 0.2 & - & - & - & - \\
\hline India & 56.0 & 59.3 & - & - & - & 1.1 & 9.4 & 9.8 \\
\hline Indonesia & 97.7 & 85.4 & 0.3 & 0.8 & - & 0.01 & 1.5 & 4.9 \\
\hline Peru & 58.8 & 54.4 & 1.6 & 5.0 & 10.5 & 12.8 & 5.3 & 0.1 \\
\hline Russian Federation & 809.3 & 814.9 & 0.0 & 0.0 & 0.0 & 0.0 & - & - \\
\hline United States & 129.2 & 130.0 & - & - & 7.3 & 7.5 & 166.6 & 172.6 \\
\hline World (58 countries) & 2748 & 2482 & 18.2 & 80.5 & 357.8 & 447.4 & 403.4 & 418.5 \\
\hline \multicolumn{9}{|c|}{$\begin{array}{l}\text { Notes: Dashes (-) denote situations in which the tenure category is not legally possible under national law. For forest area, 'RRI largely relies on ... data } \\
\text { submitted by national governments to the FAO as input to the Global Forest Resources Assessment, which is published every five years. However, RRI } \\
\text { may instead utilise alternate data concerning countries' total forest area where more recent or accurate information is available through other sources' (RRI } \\
\text { 2018: 26). } \\
\text { Source: Own elaboration based on data for } 58 \text { countries by RRI (2018); share of global forest area based on comparison between } 2017 \text { data from RRI (2018) } \\
\text { and } 2015 \text { data from FAO (2016) }\end{array}$} \\
\hline
\end{tabular}


world's forests in 2015 as defined by governments was the supply of forest products (31 per cent), protection of soil and water (31 per cent), multiple use (28 per cent) and conservation of biodiversity (13 per cent) (FAO 2016). ${ }^{5}$ Important differences exist between countries with centralised governance and those with strong decentralisation (Larson and Soto 2008). Countries also differ regarding interactions between government agencies in charge of forests and those looking after other sectors, with implications for the role of forests in development strategies and the potential for private investments (Agrawal et al. 2013).

\section{INTERNATIONAL AND LOCAL NGOS}

NGOs often play an important role in technical assistance, capacity building and advocacy in support of liaisons between local communities, value chain stakeholders and governments. They have been instrumental in developing voluntary standards for sustainable forest management (SFM) and tree crop sectors (e.g. oil palm, cocoa). In countries where financial and human resources of government agencies have been downscaled due to structural adjustments, NGOs are critical for promoting development alternatives. In remote forest areas, they may be the only providers of technical and other services. Given their capacity to mobilise financial resources, international NGOs tap into funding streams that local NGOs find difficult to access. The latter, in turn, provide the expertise and local embeddedness needed for international NGOs to run impactful projects.

\section{MULTINATIONAL AND NATIONAL COMPANIES}

The corporate sector is another key actor, from multinational companies to those operating in national domains. Given the intrinsic nature of global FPVC, companies may make important contributions to SDG 8 in terms of employment generation, decent work, and sustainability of the natural resource base. Multinational companies are well placed to contribute to international agendas, such as the New York Forest Declaration where they represent 57 out of a total of 191 endorsing organisations (Climate Focus 2017). Private companies can also access emerging finance opportunities aligned with goals such as zero deforestation and programmes aimed at generating employment in the forest sector (FAO 2018). Transitioning towards SFM by private companies requires a combination of regulatory policies and financial instruments to restructure operations and spur technological innovation. Through public-private partnerships, multinational and national companies can shape the design and implementation of sustainability standards and practices along different nodes of FPVC.

${ }^{5}$ In some cases, multiple objectives have been set for forests - shares therefore do not add up to 100 per cent. 


\section{CORPORATE ASSOCIATIONS}

Individual key actors and stakeholders may organise into corporate associations for better representation of their interests. In the natural resource sectors, such associations include the chambers of commerce, industry associations (wood, oil, gas, coal, tourism) and commodity associations (metals and minerals, crops, livestock). These associations may advance corporate social responsibility and, in the forest sector, may represent community forestry groups (e.g. Federation of Community Forestry Users, Nepal and Association of Forest Communities of Petén, Guatemala). Community-based associations can play important advocacy roles for SFM through community stewardship (Stoian et al. 2019). However, corporate associations may also promote agendas that effectively lead to deforestation - for example, through expansion of tree crop production (Benami et al. 2018) or hydroelectric dams (Fearnside 2016).

\section{SMALL AND MEDIUM ENTERPRISES}

Small and medium forest enterprises (SMFEs) often make up 80-90 per cent of the forest enterprises in tropical countries, and account for more than 50 per cent of forest-related jobs (Macqueen 2008). Their operations span timber, NTFP and ecotourism activities. Exact figures are scarce due to the high degree of informality in the SMFE sub-sector. Quantifying and addressing informal sectors in forestry can increase the availability of decent work among disenfranchised populations (FAO 2018). For SMFEs to develop into viable businesses, enabling environments are required that promote legal access to forest resources; incentives for sound forest management and value-adding; and the building of human, social, physical and financial capitals for sustainable production of timber and NTFPs (Donovan et al. 2006). Community forest enterprises (CFEs) are a subset of SMFEs with specific challenges: (1) legal entities that rarely address their realities and needs; (2) low levels of productivity and quality due to limited processing and management skills; (3) undercapitalisation; (4) long phases to reach maturity (often 20-40 years); and (5) limited participation of women in leadership positions and decision making (Stoian et al. 2009).

\section{INDIGENOUS AND NON-INDIGENOUS GROUPS DEPENDENT ON FORESTS}

The number of people relying on forests for some part of their livelihood and income is estimated at 1-1.6 billion, but reliable quantitative data for global estimates are not available (Agrawal et al. 2013). Many forest-dependent people are not organised or, if they are, are informally organised. In addition to legally constituted CFEs, there is a considerable number of unregistered forest producer organisations that can make important contributions to SFM and the generation of employment and income. This potential is yet to be fully exploited as local communities own or have been assigned use rights for more 
than 500 million ha of forests (Table 8.2), along with significant portions of forest they manage under customary rights that are not yet formally recognised. In many tropical countries, statutory and customary tenure regimes overlap, leaving local communities in a weak legal status (Wily 2011).

\subsubsection{Natural Resource Sectors and Their Contributions to National Economies}

\section{SECTORS DEPENDENT ON NATURAL RESOURCES}

The forest sector is but one of the natural resource sectors contributing to national economies and it often competes with these for land, investments and human resources. Such sectors include agriculture, energy (large-scale fossil fuel exploitation and hydro dams), minerals and metals, and ecotourism. When anticipating the impact of SDG 8 on the forest sector it is important to account for the contributions of these sectors to GDP, as governments may pursue growth policies focusing on natural resource sectors other than forestry given their weight in national economies.

Natural capital is the most or second-most important asset in low-income and lower-middle-income countries, constituting 47 and 27 per cent, respectively, of wealth in 2014 (Lange et al. 2018). It comprises both renewable (agricultural land, forests, protected areas) and non-renewable resources (fossil fuels and minerals/metals). Contributions of the non-renewables sectors to GDP generally outweigh those from the forest sector (Table 8.3), often coupled with significant environmental pressure (Schandl et al. 2016).

Table 8.3 shows that in the Top10-LFA, contributions of forest rents to GDP are low relative to those of other natural resource sectors - typically below 1 per cent. ${ }^{6}$ Most of these countries rely on natural resources other than forests, with contributions to GDP of up to 11 per cent. Excluding DR Congo, forest rents contribute less than one-tenth of total natural resource rents in these countries. At the same time, household income in forest-rich regions often relies to a much higher extent on forest resources (Angelsen et al. 2014). Accounting for these additional contributions requires addressing informality in the forest sector and developing national-level statistics beyond GDP measurement. Indicators 8.1.1 and 8.2.1 alone will not capture the full value of forest-sector contributions to economic growth and productivity.

\section{FOREST SECTOR}

On a global scale, the formal forest sector is a relevant source of employment and gross value added, totalling 13.2 million employees and USD 606 billion, respectively, in 2011 (Table 8.4).

${ }^{6}$ The case of DR Congo is ambiguous, given the significant difference between World Bank and FAO data. 
Table 8.3 Contributions of forest and other natural resource sectors to GDP in top 10 countries with largest forest area and the world in 2016, by forest area as per cent of land area

\begin{tabular}{|c|c|c|c|c|c|c|c|c|c|}
\hline & \multirow{2}{*}{$\begin{array}{l}\text { Forest area } \\
\text { (million ha) }\end{array}$} & \multirow{2}{*}{$\begin{array}{l}\% \text { of } \\
\text { land area }\end{array}$} & \multicolumn{6}{|c|}{ Rents (\% of GDP) } & \multirow{2}{*}{$\begin{array}{l}\text { Forest as } \% \text { of } \\
\text { total nat. res. rents }\end{array}$} \\
\hline & & & $\begin{array}{l}\text { Total natural } \\
\text { resources }\end{array}$ & Oil & Gas & Coal & Mineral & Forest & \\
\hline DR Congo & 152.6 & 67 & 32.7 & 0.4 & 0 & 0 & 13.2 & 19.1 * & 58 \\
\hline Brazil & 493.6 & 59 & 3.1 & 1 & 0 & 0 & 1.4 & 0.7 & 23 \\
\hline Peru & 74.0 & 58 & 7.7 & 0.5 & 0.2 & 0 & 6.7 & 0.2 & 3 \\
\hline Indonesia & 91.0 & 53 & 2.5 & 0.6 & 0.2 & 0.5 & 0.7 & 0.5 & 20 \\
\hline Russian Federation & 815.0 & 50 & 11.5 & 7 & 2.7 & 0.3 & 1 & 0.4 & 3 \\
\hline Canada & 347.1 & 38 & 1.0 & 0.3 & 0 & 0.1 & 0.6 & 0.1 & 10 \\
\hline United States & 310.1 & 34 & 0.3 & 0.1 & 0 & 0.1 & 0.1 & 0 & 0 \\
\hline India & 70.7 & 24 & 1.9 & 0.4 & 0.1 & 0.8 & 0.4 & 0.3 & 16 \\
\hline China & 208.3 & 22 & 1.1 & 0.3 & 0 & 0.3 & 0.4 & 0.1 & 9 \\
\hline Australia & 124.8 & 16 & 5.5 & 0.2 & 0.2 & 0.5 & 4.5 & 0.1 & 2 \\
\hline World & 3999 & 27 & 1.9 & 1 & 0.2 & 0.1 & 0.4 & 0.2 & 11 \\
\hline \multicolumn{10}{|c|}{$\begin{array}{l}\text { Notes: Natural resource rents are World Bank staff estimates based on sources and methods described in Lange et al. (2018). Forest rents are roundwood } \\
\text { harvest times the product of regional prices and a regional rental rate. } \\
\text { *This figure is inconsistent with the } 18.6 \% \text { contributions to GDP reported by World Bank (2018a) for the combined agricultural, fishery and forest sectors in } \\
\text { DR Congo for 2016; it is also in stark contrast to the } 0.6 \% \text { reported by FAO (2014) as contributions of the forest sector to GDP in DR Congo in } 2011 \text { - World } \\
\text { Bank (2017) reports } 18.5 \% \text { for } 2011 . \\
\text { Source: Own elaboration based on data for forest area in } 2015 \text { (FAO 2016) and World Development Indicators for contributions of natural resources to GDP } \\
\text { in } 2016 \text { (World Bank 2017) }\end{array}$} \\
\hline
\end{tabular}


Table 8.4 Contribution of the formal forest sector to employment and GDP in top 10 countries richest in forest area and the world, 2011

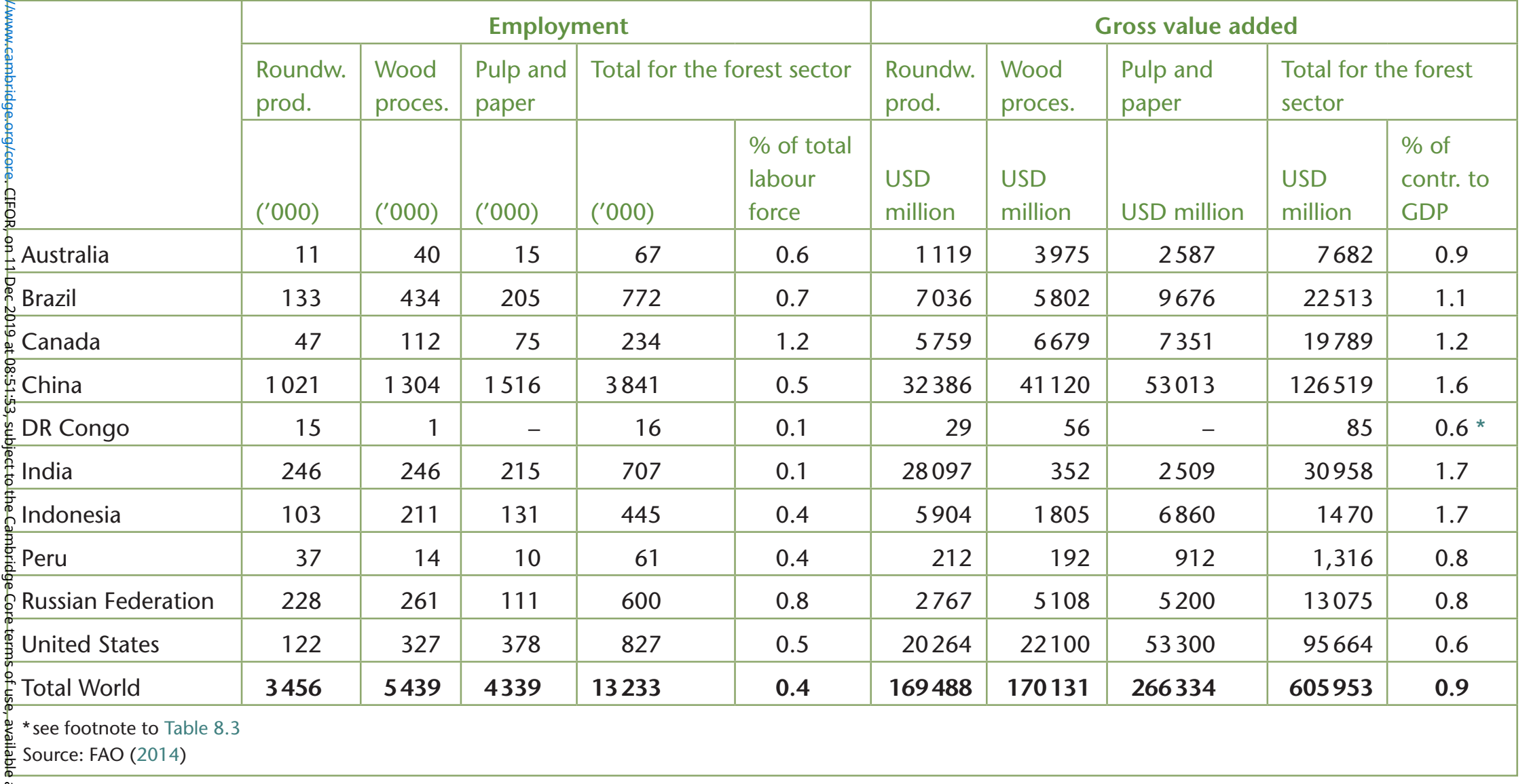


Table 8.4 illustrates that, across the Top10-LFA, $0.1-1.2$ per cent of the total labour force are employed in the forest sector - about a quarter above the global average of 0.4 per cent. However, these figures refer to formal employment in the wood-based industry only. Including informal employment and NTFP-based activities would result in considerably higher figures. The number of employees in formal and informal forest enterprises (including family businesses) is estimated at 45 million (Shackleton et al. 2011). Similarly, forest-sector contributions to GDP would probably be at least twice the official figures when allowing for the informal or non-monetary economy (Lebedys and Yanshu 2014). According to the official data in Table 8.4, the combined contributions of roundwood production, wood processing, and pulp and paper production to GDP vary by 0.6-1.7 per cent across the ten countries - roughly one-fifth above the global average of 0.9 per cent. Forest-sector contributions are relatively highest in the developing Asia-Pacific region (1.5\% of GDP), followed by sub-Saharan Africa (1.2\% of GDP) (Lebedys and Yanshu 2014).

\section{AGRICULTURAL SECTOR}

The agricultural sector is the principle source of employment in many countries of the Global South, with widely varying contributions to GDP (Table 8.5).

Table 8.5 reflects that, despite its decreased importance relative to other sectors over the past decades, the agricultural sector is the principal source of employment in the countries with the largest forest area in the Global South, with important contributions to GDP. Reductions in agricultural employment were more pronounced in emerging economies (Brazil, China, Indonesia) than in less-developed countries (DR Congo, India, Peru), but the agricultural sector still employs 10-31 per cent of the total labour force in the former and 28-82 per cent in the latter. From 2000 to 2016, sector contributions to GDP in the Top10-LFA decreased from 11 to 8 per cent. Still, they are roughly double those at the global scale, which decreased from 5 to 4 per cent. In most of these countries, the decrease of GDP contributions was well below that of employment, pointing at increased efficiencies and higher value added in the agricultural sector vis-à-vis other sectors. DR Congo diverts from this trend as contributions to GDP reflect a marked decline despite the sector's fairly stable importance in terms of employment relative to other sectors. At the same time, Brazil's agricultural sector slightly increased GDP contributions, although employment as part of the total labour force decreased by about a half.

The combined contributions of agriculture, forestry and fishing to GDP (Table 8.5) can be compared with the specific forest-sector contributions (Table 8.4). With the caveat that datasets and reference years vary, it can be 
Table 8.5 Employment in the agricultural sector between 2000 and 2017 and its contribution to GDP from 2000 to 2016 in the top 10 countries with largest forest area and the world

\begin{tabular}{|c|c|c|c|c|c|c|c|c|}
\hline & \multicolumn{4}{|c|}{$\begin{array}{l}\text { Employment (\% of total } \\
\text { employment) }\end{array}$} & \multicolumn{4}{|c|}{ Contribution to GDP (\%) } \\
\hline & 2000 & 2010 & 2017 & $\begin{array}{l}\text { Trend } \\
2000- \\
2017\end{array}$ & 2000 & 2010 & 2016 & $\begin{array}{l}\text { Trend } \\
2000- \\
2016\end{array}$ \\
\hline Australia & 5 & 3 & 3 & $-47 \%$ & 3 & 2 & 2 & -22 \\
\hline Brazil & 21 & 16 & 10 & $-52 \%$ & 5 & 4 & 5 & +3 \\
\hline Canada & 3 & 2 & 2 & $-41 \%$ & n.d. & 1 & n.d. & n.d. \\
\hline China & 44 & 26 & 18 & $-60 \%$ & 15 & 10 & 9 & -42 \\
\hline DR Congo & 85 & 80 & 82 & $-3 \%$ & 32 & 21 & 19 & -42 \\
\hline India & 60 & 52 & 43 & $-28 \%$ & 22 & 18 & 16 & -25 \\
\hline Indonesia & 45 & 39 & 31 & $-31 \%$ & 16 & 14 & 13 & -14 \\
\hline Peru & 35 & 28 & 28 & $-20 \%$ & 8 & 7 & 7 & -13 \\
\hline $\begin{array}{l}\text { Russian } \\
\text { Federation }\end{array}$ & 14 & 8 & 7 & $-54 \%$ & 6 & 3 & 4 & -27 \\
\hline United States & 2 & 2 & 2 & $-9 \%$ & 1 & 1 & 1 & -12 \\
\hline Total World & 39 & 31 & 26 & $-32 \%$ & 5 & 4 & 4 & -29 \\
\hline
\end{tabular}

Notes: contribution of agricultural sector to GDP as value added of agriculture, forestry and fishing; n.d. = no data available

Source: Own elaboration based on World Development Indicators (World Bank 2018a, 2018b)

deducted that contributions of agriculture (and fishing) to GDP in the Top10LFA are, on average, more than ten times those of the forest sector. At the same time, agricultural commodities such as soy, palm oil and beef are closely linked with deforestation. The associated loss of ecosystem services (e.g. in Brazil, Indonesia and Peru) points towards unsustainable development pathways (Carrasco et al. 2017a). On a global scale, agriculture contributes about one-quarter of greenhouse gas emissions, and decoupling these from agricultural production will remain a major challenge (Bennetzen et al. 2016).

\section{TOURISM SECTOR}

Tourism is another important source of employment, contributions to GDP and economic growth. In 2017, direct and total contributions of Tourism and Travel to global employment were 3.8 and 9.9 per cent; and to GDP, 3.2 and 
10.4 per cent, respectively (WTTC 2018). The tourism sector significantly encourages economic growth, but it also degrades the quality of the environment (Danish and Wang 2019). This general picture needs to be modified with a view on nature-based tourism and, specifically, ecotourism. However, the exact delimitation and size of these sub-sectors are difficult to establish, and there is no universally accepted definition of ecotourism. In connection with the effects of SDG 8 on forests and Target 8.9 (policies to promote sustainable tourism), different types of ecotourism need to be considered. In the Global South, the focus should shift from modernist forms of ecotourism, aimed at mere economic development, to more locally controlled, participatory forms of community-based ecotourism (Regmi and Walter 2017).

In terms of environmental performance, there is evidence for both positive and negative impacts of ecotourism (Buckley 2018). A recent global systematic review of ecotourism impacts on forests in biodiversity hotspots found that ecotourism, as typically practised, leads to local deforestation due to increased demand for fuelwood, food and timber; but when accompanied by conservation mechanisms (e.g. protected area, ecosystem service payments, monitoring/enforcement), it can protect forests (Brandt and Buckley 2018). As ecotourism often implies visiting relatively remote areas, and significant numbers of ecotourists use long-haul air travel to reach to tropical destinations, its carbon footprint can be considerable (see Gale 2016).

\section{MINING SECTOR}

On a global scale, the mining of metals and minerals contributes to regional and national economies by generating budget and export revenues, employment and infrastructure development, while it is also responsible for causing a wide range of adverse environmental and social impacts (e.g. disruption of river flows, degradation of land and forest resources, impacts on livelihoods in local communities and disturbance of indigenous people's traditional lifestyles) (Yakovleva 2017). Compared with other industrial sectors, the mining industry faces some of the most difficult sustainability challenges (Azapagic 2004). Mining of minerals and metals is an important driver of deforestation in tropical countries, often far beyond operational lease boundaries and paired with contamination of soils and aquifers (Mwitwa et al. 2012). Different types of mining impacts can be distinguished (Megevand et al. 2013): the direct impact on forest cover may be fairly limited, but indirect impacts tied to larger infrastructure developments (e.g. power plants, dams, roads) can be considerable, as can be induced impacts associated with a large influx of workers (e.g. subsistence agriculture, logging, poaching) and widespread aquatic contamination through the use and discharge of toxic substances, as well as cumulative impacts related to artisanal mining, where many small individual mining sites add up to significant impacts. 


\section{ENERGY SECTOR}

Given the diversity of the energy sector, a differentiated analysis is required with a view on SDG 8. Many countries rely heavily on fossil fuels and, to some extent, nuclear energy. At the same time, the renewable energy sector is growing around the globe, based on increasing use of hydropower, wind, solar energy, wood, residues from agriculture and forestry, biogas and various types of biofuels. Energy production is in direct competition with forests for land, and is potentially linked with environmental contamination, when involving open-pit coal mining, oil exploitation, the construction of hydro dams in forested river basins such as the Amazon, Congo and Mekong (Winemiller et al. 2016) and the production of certain biofuels. In the Brazilian Amazon, both hydro dams and mining threaten protected areas, boosted by a political-legal framework supportive of both sectors (Ferreira et al. 2014).

While economic growth and decent work will progressively be sought in the renewable energy sector, the constant push back of peak oil, gas and coal as new reserves become exploitable slows down progress in the energy transition. In 2015 , only 17.5 per cent of global final energy consumption was produced through renewable energies, and only 55 per cent of this share was derived from modern forms of renewable energy, i.e. other than fuelwood and charcoal (UN 2018). The fossil fuel sector continues to be a major source of employment and economic growth, with a high environmental footprint (see O'Rourke and Connolly 2003). Similar trade-offs are reported for agricultural crops producing biofuels, such as sugarcane (Jusys 2017) and oil palm (Vijay et al. 2016).

Fossil fuel production and consumption are also the primary source of greenhouse gas emissions, with significant, mainly adverse effects on forests through climate change (Allen et al. 2010). The impacts of biofuel production and consumption on forests are more ambiguous. Biofuels produced from crops using conventional agricultural practices will likely not mitigate the impacts of climate change caused by the use of petroleum fuels, and will exacerbate stresses on water supply and quality as well as land use (Delucchi 2010).

\subsection{Assessment of Anticipated Impacts}

Before addressing the anticipated impacts of SDG 8 action on forests and forestdependent people, it is insightful to look into progress towards SFM as recently reported with relation to SDG 15 (Life on Land). Although the forest area in the world continues to decline, the rate of loss has dropped by 25 per cent from 2000-5 to 2010-15, accompanied by a general trend towards protection of forest and terrestrial ecosystems (UN 2018). But the same report also stresses that escalating biodiversity loss requires urgent actions to protect and restore ecosystems and the biodiversity they support. While net forest area gains are reported for Central/Southern Asia and Eastern/South-Eastern Asia from 2005-10 to 
2010-15, this does not necessarily imply that deforestation has halted altogether. The ongoing reduction in above-ground biomass stock in forests reported for these two regions points to continued loss or degradation of natural forests. In fact, part of the progress in net forest area change is due to the advance of plantations, which provide a very different level of ecosystem services compared to natural forests. Similarly, the largely positive trend in the proportion of forest area under legally established protected areas or long-term forest management plans does not ensure effective change on the ground unless accompanied by viable enforcement mechanisms and other enabling conditions.

\subsubsection{Forest-Based Economic Growth}

FAO (2018) holds that forests and FPVC are of critical importance for sustained economic growth, full and productive employment and decent work for all, especially in remote areas. While at the national level manufacturing, services and other natural resource sectors are principal sources of economic growth and employment, remote forest areas rely to a much higher extent on the forest sector (Angelsen et al. 2014). Yet, many tropical countries struggle to achieve sustainable work opportunities and economic growth based on their forest riches (Swamy et al. 2018). Only a few countries (e.g. Thailand and Malaysia) have successfully used their forest resources to trigger broadbased economic growth spilling over to other natural resource sectors, and from there to manufacturing and services. The nominal GDP contributions of the forest sector do not motivate policies to develop its untapped potential. At the same time, the absence of policies promoting forest-sector development underlies its widespread stagnation in tropical regions. Political disinterest can also be attributed to a general dearth of reliable data on overall contributions of forests to national economies, spanning formal and informal employment, and timber and NTFP value chains.

Fairly robust data are available for the formal forest sector, particularly as regards the wood-based industry. Global employment in the formal forest sector decreased by about 6 per cent over the past decade, from 14.0 million people in full-time equivalents in 2000 to 13.2 million in 2011 (Lebedys and Yanshu 2014). The decline was most pronounced in the forestry sub-sector ${ }^{7}(21$ per cent) and in the developed regions. Losses were partly offset by increased formal forestry employment in developing regions, where most of the estimated 41 million people in the informal forest-sector work (FAO 2014).

In the Global South, roundwood production is relatively more important than wood processing and the production of pulp and paper. Global

\footnotetext{
${ }^{7}$ FAO (2014) distinguishes three sub-sectors: forestry (roundwood production), wood processing, and pulp and paper.
} 
value-adding across the three sub-sectors has only slightly increased (5 per cent), from USD 583 billion in 2000 (at 2011 prices and exchange rates) to USD 606 billion in 2011. The pulp and paper industry contributes most to the global gross value-added (44 per cent), followed by the wood industry and the forestry sub-sector (28 per cent each). Overall distribution of value-added across the sub-sectors remained stable in the 2000s, but the share of the pulp and paper industry has recently declined (FAO 2014).

Refined metrics are needed to fully document actual and potential contributions of the forest sector to economic growth and decent work, as are sub-national policies and strategies to promote forest-sector development in regions where there are few alternatives. These, in turn, need to promote formal employment opportunities, especially for young people, reduce labour market inequality (gender pay gap), promote safe and secure working environments, and improve access to financial services to ensure sustained and inclusive economic growth (UN 2018). Given the intrinsic differences between timber and NTFP value chains, gender-differentiated approaches are required that increase employment and income opportunities for women, particularly in NTFP value chains (see Sunderland et al. 2014).

The positive impact of SDG 8 on the forest sector may be supported by voluntary sustainability standards. Forest certification has had positive effects on indicators related to decent work, particularly regarding social security and forest worker safety (see Cashore et al. 2006). There is little evidence, however, that forest certification leads to significant economic growth in tropical countries (Romero et al. 2017). Similarly, the advance of 'zero deforestation' and similar eco-labels for agricultural commodities associated with deforestation (e.g. soy, palm oil, cocoa) have yet to show significant impacts on forest loss (van der Ven et al. 2018).

Looking forward, the potential of the forest sector to contribute to SDG 8 largely relates to developing markets and value chains for sustainable timber and NTFPs that stimulate economic growth, provide gender- and agedifferentiated employment opportunities, and ensure forest conservation. In tropical and other forest regions, sustainable tourism has the potential for promoting both economic growth and decent work. Where robust mechanisms can be established, such endeavours may be complemented with payments for environmental services.

\subsubsection{Decent Work along Forest Product Value Chains}

ILO's guiding framework for international labour standards comprises 8 fundamental, 4 governance and 177 technical conventions. One of the fundamental conventions and 6 technical ones were crafted after ILO's 
proclamation of 'decent work' in 1999. The fundamental one relates to the Worst Forms of Child Labour Convention (1999), and the pertinent technical ones are Maternity Protection (2000), Safety and Health in Agriculture (2001) and Promotional Framework for Occupational Safety and Health (2006) (ILO 2018b). While the other fundamental conventions predate the proclamation of decent work, they are closely linked to the concept. Table 8.6 illustrates the status of these conventions for the Top10-LFA.

Table 8.6 shows that five of the Top10-LFA have ratified all eight of ILO's fundamental conventions: Canada, DR Congo, Indonesia, Peru and the Russian Federation. Two conventions crucial for SMFE development have yet to be ratified by several countries: Freedom of Association \& Protection of the Right to Organise, and Right to Organise \& Collective Bargaining. In addition, effective enforcement mechanisms need to be in place to ensure these rights, as shown in countries where conventions have been ratified but implementation is lacking (e.g. DR Congo).

Several ILO conventions have direct links with SDG 8 targets and indicators, particularly Targets 8.3 (SMEs), 8.5 (productive employment and decent work), 8.6 (youth employment), 8.7 (forced labour) and 8.8 (labour rights and safety). While most Top10-LFA have ratified the conventions pertinent to Target 8.5 (except China and the United States), they lag behind in the ratification of those relating to Targets 8.3 (rights to organise), 8.6 (night work of young persons) and 8.8 (night work of women, migrant workers). The latter is particularly problematic as women and migrant workers play prominent roles in the informal forest sector. This underlines the importance of enabling environments comprising the ratification of international conventions, their translation into national policies and the formalisation of all nodes of FPVC.

Decent work may also be offered in tree crop value chains by enterprises engaged in larger schemes that replace natural forests: for example, oil palm, rubber, timber and cocoa plantations. Employment effects are often significant but, in addition to environmental externalities, labour conditions may be precarious (e.g. labour safety in sawmills, exposure to agrochemicals). Labour conditions in the first nodes of forest product and tree crop value chains may become less attractive to the younger generation which, through increased availability of educational services in rural areas, are prompted to search out livelihood options other than forestry or agriculture. At the same time, better formal education fosters skills required for developing SMFE that provide local opportunities for educated youth. Along with better access to modern information and communication technologies (ICT), there will be increased opportunities for them as managers of such enterprises. 


\begin{tabular}{|c|c|c|c|c|c|c|c|c|}
\hline \multirow[t]{2}{*}{ Convention } & 29 & 87 & 98 & 100 & 105 & 111 & 138 & 182 \\
\hline & $\begin{array}{l}\text { Forced } \\
\text { labour }\end{array}$ & $\begin{array}{l}\text { Freedom of } \\
\text { association } \\
\& \text { protection } \\
\text { of the right } \\
\text { to organise }\end{array}$ & $\begin{array}{l}\text { Right to } \\
\text { organise \& } \\
\text { collective } \\
\text { bargaining }\end{array}$ & $\begin{array}{l}\text { Equal } \\
\text { remu- } \\
\text { neration }\end{array}$ & $\begin{array}{l}\text { Abolition } \\
\text { of forced } \\
\text { labour }\end{array}$ & $\begin{array}{l}\text { Discrimi- } \\
\text { nation }\end{array}$ & $\begin{array}{l}\text { Minimum } \\
\text { age }\end{array}$ & $\begin{array}{l}\text { Worst forms } \\
\text { of child } \\
\text { labour }\end{array}$ \\
\hline Australia & $\mathrm{R}$ & $\mathrm{R}$ & $\mathrm{R}$ & $\mathrm{R}$ & $\mathrm{R}$ & $\mathrm{R}$ & NR & $\mathrm{R}$ \\
\hline Brazil & $\mathrm{R}$ & NR & $\mathrm{R}$ & $\mathrm{R}$ & $\mathrm{R}$ & $\mathrm{R}$ & $\mathrm{R}$ & $\mathrm{R}$ \\
\hline Canada & $\mathrm{R}$ & $\mathrm{R}$ & $\mathrm{R}$ & $\mathrm{R}$ & $\mathrm{R}$ & $\mathrm{R}$ & $\mathrm{R}$ & $\mathrm{R}$ \\
\hline China & NR & NR & NR & $\mathrm{R}$ & NR & $\mathrm{R}$ & $\mathrm{R}$ & $\mathrm{R}$ \\
\hline DR Congo & $\mathrm{R}$ & $\mathrm{R}$ & $\mathrm{R}$ & $\mathrm{R}$ & $\mathrm{R}$ & $\mathrm{R}$ & $\mathrm{R}$ & $\mathrm{R}$ \\
\hline India & $\mathrm{R}$ & NR & NR & $\mathrm{R}$ & $\mathrm{R}$ & $\mathrm{R}$ & $\mathrm{R}$ & $\mathrm{R}$ \\
\hline Indonesia & $\mathrm{R}$ & $\mathrm{R}$ & $\mathrm{R}$ & $\mathrm{R}$ & $\mathrm{R}$ & $\mathrm{R}$ & $\mathrm{R}$ & $\mathrm{R}$ \\
\hline Peru & $\mathrm{R}$ & $\mathrm{R}$ & $\mathrm{R}$ & $\mathrm{R}$ & $\mathrm{R}$ & $\mathrm{R}$ & $\mathrm{R}$ & $\mathrm{R}$ \\
\hline $\begin{array}{l}\text { Russian } \\
\text { Federation }\end{array}$ & $\mathrm{R}$ & $\mathrm{R}$ & $\mathrm{R}$ & $\mathrm{R}$ & $\mathrm{R}$ & $\mathrm{R}$ & $\mathrm{R}$ & $\mathrm{R}$ \\
\hline United States & NR & NR & NR & NR & $\mathrm{R}$ & NR & NR & $\mathrm{R}$ \\
\hline
\end{tabular}




\subsubsection{Forest-Dependent Livelihoods}

Forest-dependent people vary widely, as do their relationships with forests (e.g. formal or customary rights), their livelihoods (e.g. forest and non-forest activities) and their demands on forests and the broader resource system (e.g. products and ecosystem services). Official accounts rarely capture the intrinsic nature of such relationships and tend to underestimate the monetary and non-monetary values of forests to these people and society. As forests continue to be degraded or converted to other land uses, forest-dependent people may be forced into other livelihood activities in their respective locations, move further into the forest or out-migrate altogether. At the same time, the rights of forest-dependent communities are progressively being recognised (RRI 2017), providing an institutional environment enabling them to determine livelihood shifts more autonomously rather than responding to externally driven pressures.

\subsubsection{Gender, Intergenerational and Ethnic Equity}

Empowerment of forest-dependent communities, including participation in decision making and strengthening of livelihoods, is closely linked to gender, age and ethnicity. Access to land and natural resources is a critical entry point for empowering women and marginalised groups as it defines social status and political power and structures relationships within and outside the household (Agarwal 1994). Official statistics on differentiated access to forest resources are scarce, as is information on women, youth and other vulnerable groups in relation to their participation as labour force in the forest sector. Given the often seasonal nature of forest-based activities, their participation tends to be intermittent, informal and underpaid (FAO 2018).

This lack of recognition influences policymaking. In many cases, women, indigenous peoples and other marginalised groups are not considered beneficiaries unless programmes target them explicitly (Larson et al. 2018). Despite important gender differentiation in the collection of forest products, with distinctive 'male' and 'female' roles (Sunderland et al. 2014), forests continue to be perceived as a 'male domain' and development interventions are often designed accordingly. Combined, these factors tend to perpetuate the position of women and other marginalised groups in the informal part of the forest sector, with the associated underestimation of their contributions to sector development. In countries such as Guatemala and Cameroon, where community rights to forests are formalised and where internal governance structures do not unduly favour male dominance or that of certain economic strata, women, youth and indigenous peoples can play important roles in the management of CFEs (see Belibi et al. 2015, Stoian et al. 2019). 


\subsubsection{Forest Conservation}

Despite a 15 per cent reduction in the global rate of net forest loss from 1990 to 2015 (FAO 2016), forests and associated biodiversity continue to be threatened. While SDG 8 seeks to decouple economic growth from environmental degradation, there is also an opportunity to couple economic growth with forest conservation and sustainable resource management. For example, communitybased forest management can link forest conservation with economic growth and livelihoods improvement through SMFE development and tourism (Macqueen et al. 2018). The relationship between forest concessions managed by private companies, forest conservation and local economic development is less clear (see FAO and EFI 2018). While inappropriate logging can lead to forest degradation, the primary drivers of deforestation lie outside the forest sector: commercial and subsistence/local agriculture, followed by infrastructure development, mining and urban sprawl (Hosonuma et al. 2012).

Forest conservation needs to be achieved from both outside, by checking extra-sectoral drivers of deforestation, and from within through SFM or preservation with limited human intervention. A comparative analysis of 40 protected areas and 33 community-managed forests showed that annual deforestation rates in the latter were lower and less variable than those in protected forests; forest conservation strategies should therefore encompass a regional differentiation of land use types, tenure rights, social and economic needs of local inhabitants, and local capacities (Porter-Bolland et al. 2012).

In regions where deforestation has been reduced or halted, opportunities exist for initiating landscape restoration. Diverse combinations of agroforestry systems and timber plantations can stimulate economic growth and recover ecosystem services, with the bottom line that forest, agroforestry and plantation forestry options generate income comparable to alternative land uses (Appanah 2016).

\subsubsection{Anticipated Impacts within the Framework of SDG 8}

Principal synergies between SDG 8 and forests can be expected for areas where national policies for economic growth and decent work explicitly target the forest sector, and where these are paired with adequate legislation for sustainable management and conservation of forests and effective enforcement mechanisms. Several tropical countries provide monetary incentives for carbon sequestration through reforestation (Baker et al. 2019), with payments typically varying between USD 800 and USD 1500 per ha. The establishment of timber plantations has important employment effects, as shown for Brazil, China and Indonesia (Tomberlin et al. 2001). Some countries also provide incentives for managing natural forests for timber and NTFPs (Agrawal et al. 
2018), generating local employment and value added. Community-based forest management and processing of forest products by CFEs can be combined with ecotourism to generate additional employment and income, as documented for Petén, Guatemala (Stoian et al. 2019).

While such synergies have important employment effects at local and regional levels, their impact at national and global scales will continue to be modest in light of the limited contributions of the forest sector to GDP 0.2 per cent worldwide and 0.7 per cent in lower-middle-income countries (World Bank 2017). Accounting for the informal sector could double forestsector contributions to GDP (World Bank 2016), but contributions of other natural resource sectors will continue to outperform those of the forest sector in many tropical countries. This holds particularly for the agricultural and mining sectors and, depending on the energy mix in a given country, the energy sector. Most governments have long pursued growth strategies based on modernisation and economic growth theories. Without a major paradigm shift, national policies will continue to prioritise the natural resource sectors that contribute most to GDP.

Principle trade-offs within SDG 8 implementation, particularly as regards deforestation, relate to policies for competing natural resource sectors. But some trade-offs are also expected for areas of potential synergy. For example, a systematic review of the socio-economic impacts of large-scale tree plantations found ambiguous impacts: slightly positive for employment, mixed regarding livelihoods and negative for land and intertwined social factors (Malkamäki et al. 2018). Strong global evidence on long-term socio-economic impacts of large-scale tree plantations remains limited (Malkamäki et al. 2018). Similarly, the evidence base for inferring positive effects between ecotourism and forests is insufficient (Brandt and Buckley 2018). A recent review on development policies in relation to the SDGs found that many commonly applied development interventions do not explicitly consider natural resources, let alone forests, leading to suboptimal, unsustainable outcomes; even if interventions tackle both development and conservation goals, they often lack coordination and sufficient levels of natural capital to ensure longterm sustainability (Miteva 2019).

\subsection{Synergies and Trade-Offs between SDG 8 and Other SDGs}

With the aim to maximise synergies and minimise trade-offs with other SDGs, partnerships for working towards SDG 8 have emerged at global, regional and national levels. As of February 2019, the SDG Knowledge Platform lists 770 partnerships in relation to SDG 8 (UN 2019). The World Bank Group alone 
reports more than 570 active projects with a jobs angle, representing investments of close to USD 75 billion, reaching nearly 2 million new beneficiaries and leveraging additional investments through global partnerships (World Bank 2018c). The United Nations Conference on Trade and Development (UNCTAD) and its partners seek to mainstream the promotion of investment in SDG sectors and to build capacity for SDG-related projects (UNCTAD 2018).

For assessing potential synergies and trade-offs, we developed a matrix that juxtaposes SDG 8 with other SDGs. We first reviewed connecting targets and assessed interaction intensity (high, medium, low) and then, from the perspective of the forest resource base, forest-dependent people and the forest industry, we considered the nature of the interactions (synergies, neutral, trade-offs) in dependence on political-strategic priorities (Table 8.7).

Table 8.7 illustrates that, in relation to the forest sector, SDG 8 has strong interactions with SDGs 1, 2, 5, 7, 9, 10, 12, 13, 15, and 17. At the same time, interactions between SDG 8 and SDGs 3, 6, 11, 14 and 16 are less strong, and those with SDG 4 are important but relatively indirect. Our assessment is in line with the literature showing that forests are important to the success of many of the sectors and functions represented within the context of the SDGs. In an assessment depicting the SDGs as a network of linked targets, SDG 8 ranks third as regards the number of SDGs it is connected with (10), including strong links with SDGs 9 and 10 (3 linked targets each), followed by SDGs 12 and 14 ( 2 targets each) and SDGs 1, 2, 4, 13, 15 and 16 (1 target each) (Le Blanc 2015). Diversions from our assessment owe to our focus on the forest sector.

Synergies between SDG 8 and other SDGs regarding forest-dependent people, the forest industry and the forest resource base are likely in countries where policies and strategies explicitly focus on the forest sector and are accompanied by safeguards for SFM and forest conservation. Such synergies can be expected as regards poverty reduction (SDG 1), clean water (SDG 6), 'modern' renewable energies (SDG 7), forest industry development (SDG 9), reduced (gender) inequalities in FPVC (SDGs 5 and 10), safe and affordable housing based on materials derived from forests (SDG 11), responsible consumption of forest products (SDG 12), economic growth through forests managed and protected as carbon sinks (SDG 13) and sustainable forest products and ecotourism (SDG 15).

Trade-offs for forests are anticipated in countries where policies and strategies focus on other natural resource sectors, particularly agriculture, energy and mining. A principal challenge is the significant increase of global food production required to feed the world's growing population (FAO 2018). Major trade-offs are anticipated between SDG 8 on the one hand, and SDGs 2, 13 and 15 on the other. Other trade-offs exist between the forest and mining 
Table 8.7 Intensity and nature of interactions between SDG 8 and other SDGs in relation to the forest sector and depending on political-strategic priorities

\begin{tabular}{|c|c|c|}
\hline SDG 8 & $\begin{array}{l}\text { Intensity of interactions } \\
\text { High (dark grey) } \\
\text { Medium (mid-grey) } \\
\text { Low (light grey) }\end{array}$ & $\begin{array}{l}\text { Nature of interactions depending on political-strategic priorities } \\
\text { Synergies (yellow) } \\
\text { Neutral (orange) } \\
\text { Trade-offs (red) }\end{array}$ \\
\hline \multirow[t]{4}{*}{ SDG 1 - No Poverty } & & $\begin{array}{l}\text { Nature of interactions depends on sector focus of policies and strategies to foster } \\
\text { employment and income for the poor: }\end{array}$ \\
\hline & & $\begin{array}{l}\text { Growth of the forest sector and ecotourism can generate additional employment } \\
\text { and income for poor forest-dependent people. }\end{array}$ \\
\hline & & $\begin{array}{l}\text { Growth of manufacturing and service sectors with low demand for natural } \\
\text { resources may generate limited additional employment and income for poor } \\
\text { forest-dependent people and be largely neutral to the forest resource base. }\end{array}$ \\
\hline & & $\begin{array}{l}\text { Growth of other natural resource sectors may jeopardise livelihoods of poor forest- } \\
\text { dependent people due to deforestation. }\end{array}$ \\
\hline \multirow[t]{3}{*}{ SDG 2 - Zero Hunger } & & Nature of interactions depends on the type of agriculture promoted: \\
\hline & & $\begin{array}{l}\text { Sustainable intensification of agriculture and lower demand for animal-based food } \\
\text { can contribute to zero deforestation over time, retaining options for forest-sector } \\
\text { growth. }\end{array}$ \\
\hline & & $\begin{array}{l}\text { Some forms of commercial and subsistence agriculture are primary drivers of } \\
\text { deforestation, limiting forest-sector growth. }\end{array}$ \\
\hline
\end{tabular}


Table 8.7 (cont.)

\begin{tabular}{|c|c|c|}
\hline SDG 8 & $\begin{array}{l}\text { Intensity of interactions } \\
\text { High (dark grey) } \\
\text { Medium (mid-grey) } \\
\text { Low (light grey) }\end{array}$ & $\begin{array}{l}\text { Nature of interactions depending on political-strategic priorities } \\
\text { Synergies (yellow) } \\
\text { Neutral (orange) } \\
\text { Trade-offs (red) }\end{array}$ \\
\hline \multirow[t]{4}{*}{$\begin{array}{l}\text { SDG } 3 \text { - Good Health } \\
\text { and Well-being }\end{array}$} & & $\begin{array}{l}\text { Nature of interactions depends on the sector focus of policies and strategies to foster } \\
\text { economic growth and decent work: }\end{array}$ \\
\hline & & $\begin{array}{l}\text { Advancing decent work in the forest sector reduces occupational injuries; } \\
\text { investments by CFEs in health facilities and services can improve the health of their } \\
\text { members. }\end{array}$ \\
\hline & & $\begin{array}{l}\text { Growth of manufacturing and service sectors with low demand for natural } \\
\text { resources may be largely neutral to the health and well-being of forest-dependent } \\
\text { people. }\end{array}$ \\
\hline & & $\begin{array}{l}\text { Growth of other natural resource sectors may compromise health of forest- } \\
\text { dependent people: malaria (hydro dams); contamination with heavy metals } \\
\text { (mining) and agrochemicals (agriculture). }\end{array}$ \\
\hline \multirow[t]{4}{*}{$\begin{array}{l}\text { SDG } 4 \text { - Quality of } \\
\text { Education }\end{array}$} & & $\begin{array}{l}\text { Nature of interactions depends on the type, quality and location of educational } \\
\text { facilities and services available to forest-dependent people: }\end{array}$ \\
\hline & & $\begin{array}{l}\text { Forest sector and ecotourism growth may curb outmigration from forest areas and } \\
\text { spur reinvestment in education and expansion of educational services; these, in } \\
\text { turn, can help upgrade capacities and skills for managing forests and SMFE. }\end{array}$ \\
\hline & & $\begin{array}{l}\text { Upgrading general educational facilities and services is largely neutral to the forest } \\
\text { resource base and, hence, does not affect forest-sector growth. }\end{array}$ \\
\hline & & $\begin{array}{l}\text { Improved access to educational facilities may lead youth to search out livelihood } \\
\text { options other than forest-based activities. }\end{array}$ \\
\hline
\end{tabular}




\section{SDG 5 - Gender Equality}

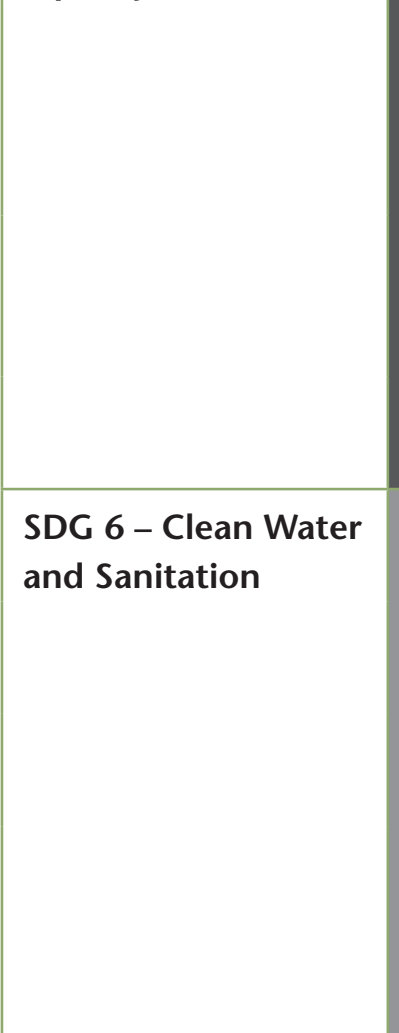

Nature of interactions depends on the sector focus of policies and strategies to foster economic growth and decent work:

Growth of forest-based ecotourism and NTFP value chains may foster gender equality; equal representation and participation in decision making of women and men in the management of forest enterprises may boost their economic and social performance.

Growth of certain segments of the energy and agricultural sectors may be largely neutral to forest-dependent people and, hence, not affect gender equality among them.

Growth of the mining sector and timber and fuelwood value chains may perpetuate gender inequalities.

Nature of interactions depends on watershed management regulations and the sector focus of policies and strategies to foster economic growth and decent work:

Forest sector growth based on SFM helps to maintain or restore forests as waterrelated ecosystems.

Growth of forest-based sustainable ecotourism may be largely neutral in terms of water availability and quality and, hence, not affect forest-sector growth.

Growth of the agricultural, mining and energy sectors and unsustainable tourism may induce deforestation and, thus, compromise water availability and quality; watershed management regulations may impose restrictions limiting forest-sector growth. 
Table 8.7 (cont.)

\begin{tabular}{|l|l|l|}
\hline SDG 8 & $\begin{array}{l}\text { Intensity of interactions } \\
\text { High (dark grey) } \\
\text { Medium (mid-grey) } \\
\text { Low (light grey) }\end{array}$ & $\begin{array}{l}\text { Nature of interactions depending on political-strategic priorities } \\
\text { Synergies (yellow) } \\
\text { Neutral (orange) } \\
\text { Trade-offs (red) }\end{array}$ \\
\hline SDG 7 - Affordable & & Nature of interactions depends on the type of energy promoted:
\end{tabular}
and Clean Energy

Growth of 'modern' renewable energies may reduce pressure on forests exploited for firewood and charcoal and, thus, provide opportunities for alternative forestsector growth.

Promotion of solar and wind energy may be largely neutral to forestry industry, forest-dependent livelihoods and the forest resource base in areas where firewood extraction is insignificant.

Construction of large-scale hydro dams may increase deforestation and, thus, limit forest-sector growth.

SDG 9 - Industry, Innovation and Infrastructure
Nature of interactions depends on the type of infrastructure promoted and the sector focus of policies and strategies to foster economic growth and decent work:

Promoting growth of the forest and ecotourism industries can create additional employment and income; road construction in forest areas can improve market access.

Developing infrastructure for economic growth in urban areas may be largely neutral to the forest resource base and, hence, not affect forest-sector growth.

Promoting growth of the agri-food, mining and energy industries and construction of roads and hydro dams may increase deforestation and, thus, limit forest-sector growth. 


\begin{tabular}{|c|c|}
\hline \multirow[t]{4}{*}{$\begin{array}{l}\text { SDG } 10 \text { - Reduced } \\
\text { Inequalities }\end{array}$} & $\begin{array}{l}\text { Nature of interactions depends on the sector focus of policies and strategies to foster } \\
\text { economic inclusion: }\end{array}$ \\
\hline & $\begin{array}{l}\text { There is high potential for economic inclusion in the forest sector where about } \\
75 \% \text { of employment is informal. }\end{array}$ \\
\hline & $\begin{array}{l}\text { Economic inclusion in the tourism sector may be largely neutral to the forest } \\
\text { resource base and, hence, not affect forest-sector growth. }\end{array}$ \\
\hline & $\begin{array}{l}\text { Economic inclusion in the agricultural, mining and energy sectors may increase } \\
\text { deforestation and, thus, limit forest-sector growth. }\end{array}$ \\
\hline \multirow{4}{*}{$\begin{array}{l}\text { SDG } 11 \text { - Sustainable } \\
\text { Cities and } \\
\text { Communities }\end{array}$} & $\begin{array}{l}\text { Nature of interactions depends on the sectors affected by urban sustainability policies } \\
\text { and strategies: }\end{array}$ \\
\hline & $\begin{array}{l}\text { Increased demand for safe and affordable housing based on wood and other } \\
\text { materials from the forest can spur forest-sector growth; demand for peri-urban } \\
\text { forests as green public spaces can foster growth of ecotourism. }\end{array}$ \\
\hline & $\begin{array}{l}\text { Urban transport and settlement policies may be largely neutral to the forest } \\
\text { resource base and, hence, not affect forest-sector growth. }\end{array}$ \\
\hline & $\begin{array}{l}\text { Urban water demand may impose restrictions on management of forest } \\
\text { resources in nearby watersheds; demand for non-polluting energies may increase } \\
\text { deforestation through expansion of hydro dams and, thus, limit forest-sector } \\
\text { growth. }\end{array}$ \\
\hline
\end{tabular}


Table 8.7 (cont.)

\begin{tabular}{|c|c|c|}
\hline SDG 8 & $\begin{array}{l}\text { Intensity of interactions } \\
\text { High (dark grey) } \\
\text { Medium (mid-grey) } \\
\text { Low (light grey) }\end{array}$ & $\begin{array}{l}\text { Nature of interactions depending on political-strategic priorities } \\
\text { Synergies (yellow) } \\
\text { Neutral (orange) } \\
\text { Trade-offs (red) }\end{array}$ \\
\hline \multirow{3}{*}{$\begin{array}{l}\text { SDG } 12 \text { - Responsible } \\
\text { Consumption and } \\
\text { Production }\end{array}$} & & $\begin{array}{l}\text { Nature of interactions depends on the sectors targeted by responsible consumption } \\
\text { and production policies and strategies: }\end{array}$ \\
\hline & & $\begin{array}{l}\text { Promotion of building materials derived from wood and other forest resources, } \\
\text { along with standards attesting their sustainability, provides incentives for forest } \\
\text { sector and ecotourism growth based on SFM. }\end{array}$ \\
\hline & & $\begin{array}{l}\text { Advance of sustainability standards attesting zero deforestation in agricultural } \\
\text { commodity chains ensures neutrality to the forest resource base and, thus, does } \\
\text { not affect forest-sector growth. }\end{array}$ \\
\hline \multirow[t]{3}{*}{$\begin{array}{l}\text { SDG } 13 \text { - Climate } \\
\text { Action }\end{array}$} & & $\begin{array}{l}\text { Nature of interactions depends on climate change regulations and the sector focus of } \\
\text { policies and strategies to foster economic growth and decent work: }\end{array}$ \\
\hline & & $\begin{array}{l}\text { Forest-sector growth based on SFM helps to maintain or restore forests as carbon } \\
\text { sinks and, thus, reduces greenhouse gas emissions; successful climate change } \\
\text { mitigation measures support forest health and, thus, forest industry and forest- } \\
\text { dependent people. }\end{array}$ \\
\hline & & $\begin{array}{l}\text { Growth of the agricultural, mining, energy and tourism sectors may increase } \\
\text { deforestation and/or greenhouse gas emissions; climate change regulations may } \\
\text { impose restrictions limiting forest-sector growth. }\end{array}$ \\
\hline
\end{tabular}




\begin{tabular}{|c|c|}
\hline \multirow[t]{3}{*}{$\begin{array}{l}\text { SDG } 14 \text { - Life Below } \\
\text { Water }\end{array}$} & $\begin{array}{l}\text { Nature of interactions depends on ocean management regulations and the sector focus } \\
\text { of policies and strategies to foster economic growth and decent work: }\end{array}$ \\
\hline & $\begin{array}{l}\text { Growth of inland aquaculture may be largely neutral to the forest resource base } \\
\text { and, hence, not affect forest-sector growth. }\end{array}$ \\
\hline & $\begin{array}{l}\text { Forest-sector growth may be limited by: ( } 1 \text { ) expansion of fish and shrimp } \\
\text { farming in coastal areas in response to regulations restricting fishing in open } \\
\text { waters, leading to deforestation of mangroves and other coastal forest types; ( } 2 \text { ) } \\
\text { regulations restricting the use of forest resources in coastal regions; ( } 3 \text { ) discharge } \\
\text { of materials from areas deforested through agriculture and mining may affect } \\
\text { growth of mangrove forests and associated forest-sector development. }\end{array}$ \\
\hline \multirow[t]{3}{*}{ SDG 15 - Life on land } & $\begin{array}{l}\text { Nature of interactions depends on protected area regulations and the sector focus of } \\
\text { policies and strategies to foster economic growth and decent work: }\end{array}$ \\
\hline & $\begin{array}{l}\text { SFM sustains forest-sector growth; expansion and management of protected areas } \\
\text { can foster growth of sustainable ecotourism. }\end{array}$ \\
\hline & $\begin{array}{l}\text { Growth of the agricultural, mining and energy sectors may increase deforestation } \\
\text { and protected area regulations may restrict forest management and, thus, limit } \\
\text { forest-sector growth. }\end{array}$ \\
\hline \multirow{3}{*}{$\begin{array}{l}\text { SDG } 16 \text { - Peace, } \\
\text { Justice and Strong } \\
\text { Institutions }\end{array}$} & $\begin{array}{l}\text { Nature of interactions depends on the focus of policies and strategies to foster peace, } \\
\text { justice and institutional strengthening: }\end{array}$ \\
\hline & $\begin{array}{l}\text { Strong local institutions promote SFM and SMFE; reduction of illicit forest-related } \\
\text { activities (illegal logging, wildlife trade, drug trafficking) linked with deforestation } \\
\text { supports forest-sector growth. }\end{array}$ \\
\hline & $\begin{array}{l}\text { Non-forest-related regulations are essentially neutral to the forest resource base } \\
\text { and, hence, do not affect forest-sector growth. }\end{array}$ \\
\hline
\end{tabular}




\begin{tabular}{|c|c|c|}
\hline $\begin{array}{l}\text { SDG } 8 \\
\text { SDGs }\end{array}$ & $\begin{array}{l}\text { Intensity of interactions } \\
\text { High (dark grey) } \\
\text { Medium (mid-grey) } \\
\text { Low (light grey) }\end{array}$ & $\begin{array}{l}\text { Nature of interactions depending on political-strategic priorities } \\
\text { Synergies (yellow) } \\
\text { Neutral (orange) } \\
\text { Trade-offs (red) }\end{array}$ \\
\hline \multirow{4}{*}{$\begin{array}{l}\text { SDG } 17 \text { - } \\
\text { Partnerships for the } \\
\text { Goals }\end{array}$} & & $\begin{array}{l}\text { Nature of interactions depends on the sector focus of policies and strategies to foster } \\
\text { economic growth, decent work and partnerships: }\end{array}$ \\
\hline & & $\begin{array}{l}\text { Private, public and civil society partnerships can foster FPVC development; } \\
\text { enhanced finance, technology, capacity development, trade and systemic support } \\
\text { for the forest sector will spur its growth and decent work. }\end{array}$ \\
\hline & & $\begin{array}{l}\text { Enhanced finance, technology, capacity development, trade and systemic support } \\
\text { for the ecotourism sector may be largely neutral to the forest resource base and, } \\
\text { hence, not affect forest-sector growth. }\end{array}$ \\
\hline & & $\begin{array}{l}\text { Enhanced finance, technology, capacity development, trade and systemic support } \\
\text { for the agricultural, mining and energy sectors may increase deforestation and, } \\
\text { thus, limit forest-sector growth. }\end{array}$ \\
\hline
\end{tabular}


sectors. World demand for mineral resources has increased significantly since 2000 and continued growth in the technology, transportation and construction sectors will further fuel demand (Megevand et al. 2013). Untapped mineral resources are concentrated in the Amazon, Congo and Mekong basins. Growth of the mining sector implies important trade-offs between SDG 8 and SDGs 3, 5, 6, 12, 13, and 15 and, in view of armed conflicts around mineral resources in forested regions (Switzer 2001), with regard to SDG 16.

Countries rich in natural resources have long been known for strong links between resource extraction and environmental degradation. This 'resource curse' often leads to forest degradation, undermining Target 8.4, which seeks to decouple economic growth from environmental degradation (Swamy et al. 2018). In Ethiopia, for example, the government has embarked on a rapid economic growth trajectory emphasising agriculture and energy development, requiring vast tracts of land and competing with other ecosystems including forests (Weitz et al. 2014).

Progress towards all SDGs depends on multiple interactions among diverse stakeholder groups. Beyond potential synergies among SDGs, there is a need for identifying common interests among key stakeholders and developing mechanisms for coordinated, collaborative efforts. Cross-sector, multi-stakeholder dialogue is also needed to address conflicting interests and minimise trade-offs. Conflict resolution and stakeholder-informed prioritisation are required as there is considerable risk that SDG actions undermine one another and compromise the sustainable use of natural resources (Swamy et al. 2018).

\subsection{Conclusions}

As most governments in the Global South are pursuing 'growth and trickledown' strategies to reduce poverty, while largely relying on natural capital, both renewable and non-renewable resources will be in high demand to achieve rapid economic growth (FAO 2010). As a result, significant trade-offs can be expected between achieving SDG 8 and SDGs focused on the conservation of natural resources, particularly SDGs 6, 13 and 15. At the country level, the effects of SDG 8 on forests will depend on the prioritisation of overarching development paradigms (modernisation, economic growth, basic needs, sustainable development) which, in turn, will lead to a differentiated prioritisation of SDG 8 targets by governments, the private sector, investors and civil society. Even in forest-rich countries such as Russia, Canada, Brazil, Indonesia and DR Congo, the contributions of the forest sector to GDP and overall economic growth are modest at best. Growth strategies are likely to continue to rely on natural resource sectors other than forestry (agriculture, energy, and 
mining), which, in many cases, directly compete with the forest sector for land, investments and human resources.

Efforts to factor forest ecosystem services into national accounts of natural capital are laudable and will play an increasing role in shaping the debate about the value of forests vis-à-vis that of alternative land uses. Still, for the foreseeable future such economic valuation of forests will hardly become a game-changer for halting deforestation and forest degradation at the global scale, given that competing sectors hold higher potential for generating economic growth, employment and, arguably, decent jobs. Decoupling economic growth from forest-related environmental degradation will continue to be a principal challenge in countries where such growth is sought by developing sub-sectors of agricultural (e.g. cereals, sugarcane, soy, beef) and tree crops (e.g. rubber, oil palm), the energy sector through expansion of hydro dams and the mining sector through granting licenses in extensive forest areas.

Conflicting growth policies and those neglecting environmental tradeoffs reflect, to some extent, the architecture of the SDGs. It is argued that the global negotiation process for SDG formulation resulted from 'political' mapping rather than biophysical and socio-economic considerations; consequently, the political framework does not explicitly reflect the multiplicity of links that matter for policy purposes, and in practice the SDGs will be of limited use in providing guidance to address those various links (Le Blanc 2015). Furthermore, despite the notion of equivalence among SDGs, interventions and investments will be guided by societal goal prioritisation. Such a process, in turn, will reflect overarching development paradigms and, depending on the access to information and decision making among stakeholder groups, varying degrees of inclusiveness as regards prioritisation.

The nature of such processes will determine the extent to which the synergetic dimension of SDG 8 will figure more prominently. This would be reflected, for example, in significant numbers of poorer people involved in the establishment and management of timber plantations, the management of natural forests for timber and NTFPs, their processing into value-added products, and services related to ecotourism and the provision of environmental services. The impact of such endeavours can be expected to grow over time as the 'green' economy, public and private sustainability standards, and impact investments advance. Increasing the community stewardship of tropical forests will further contribute to synergies between forest conservation and livelihood development, with equitable benefit sharing between men, women and youth. Community-based approaches will allow for gender-differentiated opportunities in timber and NTFP value chains. Involvement of the youth and decent work in the forest sector can increase with better access to skills development programmes and modern ICT for 
running forest-based enterprises, ensuring long-term engagement and better positioning in FPVC.

However, in many countries and for many years to come, the societal prioritisation of SDGs will continue to follow established patterns: putting economic goals over environmental and social goals. For example, donor agencies such as the Department for International Development (DFID) are returning to an economic growth agenda. Such a strategy may achieve growth in partner countries but, without sufficient conceptual rigour, regulatory oversight or attention to the 'connective fabric' between growth and development, may yield to state-corporate interests and not achieve progressive, just development outcomes (Mawdsley 2015). In general, business-as-usual approaches to economic growth will perpetuate trade-offs with regard to the conservation of forests and the livelihoods dependent on them. However, the prioritisation of goals and actions that negatively affect forests may be unavoidable in given situations. In these cases, the overall SDG outcomes need to be acceptable from a broader societal development perspective ('justified deforestation') - for example, when the benefits from agricultural conversion outweigh the environmental costs (see Carrasco et al. 2017b). For this to happen, access to information and education needs to improve, societal debate needs to become more inclusive and paradigm shifts need to happen ('decent work and decent growth'). These shifts would reflect, and can be nurtured through, alternative approaches for measuring forest-sector impact - beyond GDP contributions, employment generation and the hectarage of forests set aside as protected areas. Such approaches allow for a more integrated measurement of economic growth, assessing its environmental impact by accounting for the conservation or depletion of overall natural capital stocks and its social impact by using metrics that account for gender, age and other factors of social differentiation. Results of integrated measuring can contribute to individual and institutional learning, foster innovative cross-sector partnerships and, based on these, more informed prioritisation of goals and better targeted interventions and investments by public and private sectors and civil society.

\section{References}

Agarwal, B. 1994. Gender and command over property: A critical gap in economic analysis and policy in South Asia. World Development 22(10):1455-78.

Agrawal, A., Cashore, B., Hardin, R., Shepherd, G., Benson, C. and Miller, D. 2013. Economic contributions of forests. Background paper prepared for the 10th session of the United Nations Forum on Forests held in Istanbul, 8-19 April 2013. 
Agrawal, A., Hajjar, R., Liao, C., Rasmussen, L. V. and Watkins, C. 2018. Editorial overview: Forest governance interventions for sustainability through information, incentives, and institutions. Current Opinion in Environmental Sustainability 32:1-7.

Allen, C. D., Macalady, A. K., Chenchouni, H. et al. 2010. A global overview of drought and heat-induced tree mortality reveals emerging climate change risks for forests. Forest Ecology and Management 259(4):660-84.

Angelsen, A., Jagger, P., Babigumira, R. et al. 2014. Environmental income and rural livelihoods: a global-comparative analysis. World Development 64:S12-28.

Appanah, S. 2016. Forest landscape restoration for Asia-Pacific forests. Bangkok: FAO/RECOFTC.

Arndt, H. W. 1983. The 'trickle-down' myth. Economic Development and Cultural Change 32(1):1-10.

Azapagic, A. 2004. Developing a framework for sustainable development indicators for the mining and minerals industry. Journal of Cleaner Production 12(6):639-62.

Baker, J. S., Wade, C. M., Sohngen, B. L., Ohrel, S. and Fawcett, A. A. 2019. Potential complementarity between forest carbon sequestration incentives and biomass energy expansion. Energy Policy 126:391-401.

Belibi, M. B., van Eijnatten, J., Mala, W. A. and Ingram, V. 2015. Empowering women and ethnic minority groups to collectively market non timber forest products from community forests in Cameroon. Journal of Life Sciences 9(8):381-90.

Benami, E., Curran, L. M., Cochrane, M. et al. 2018. Oil palm land conversion in Pará, Brazil, from 2006-2014: Evaluating the 2010 Brazilian Sustainable Palm Oil Production Program. Environmental Research Letters 13(3):034037.

Bennetzen, E. H., Smith, P. and Porter, J. R. 2016. Decoupling of greenhouse gas emissions from global agricultural production: 1970-2050. Global Change Biology 22(2):763-81.

Brandt, J. S. and Buckley, R. C. 2018. A global systematic review of empirical evidence of ecotourism impacts on forests in biodiversity hotspots. Current Opinion in Environmental Sustainability 32:112-18.

Buckley, R. 2018. Impacts positive and negative: links between ecotourism and environment. In Buckley, R. (ed.) Environmental impacts of ecotourism. Wallingford: CABI Publishing, pp. 5-14.

Carrasco, L. R., Le Nghiem, T. P., Chen, Z. and Barbier, E. B. 2017a. Unsustainable development pathways caused by tropical deforestation. Science Advances 3(7):e1602602.

Carrasco, L. R., Webb, E. L., Symes, W. S., Koh, L. P. and Sodhi, N. S. 2017b. Global economic trade-offs between wild nature and tropical agriculture. PLoS Biology 15(7): e2001657.

Cashore, B., Gale, F., Meidinger, E. and Newsom, D. (eds.) 2006. Confronting sustainability: Forest certification in developing and transitioning countries. New Haven: Yale School of Forestry and Environmental Studies.

Climate Focus 2017. Progress on the New York Declaration on Forests: Finance for forests-Goals 8 and 9. Assessment report prepared by Climate Focus in cooperation with the New York Declaration on Forest Assessment Partners with support from the Climate and Land Use Alliance.

Costanza, R., Kubiszewski, I., Giovannini, E. et al. 2014. Time to leave GDP behind. Nature 505:283-5. 
Danish and Wang, Z. 2019. Dynamic relationship between tourism, economic growth, and environmental quality. Journal of Sustainable Tourism 26(11):1928-43. doi:10.1080/09669582 .2018 .1526293 .

Delucchi, M. A. 2010. Impacts of biofuels on climate change, water use, and land use. Annals of the New York Academy of Sciences 1195(1):28-45.

Donovan, J., Stoian, D., Grouwels, S. and Macqueen, D. 2006. The business side of sustainable forest management: Small and medium forest enterprise development for poverty reduction. Natural Resource Perspectives 104. London: ODI.

FAO 2010. Asia-Pacific forests and forestry to 2020. Report of the second Asia-Pacific Forestry Sector Outlook Study. Rome: FAO.

FAO 2014. The state of the world's forests - Enhancing the socio-economic benefits from forests. Rome: FAO.

FAO 2016. Global Forest Resources Assessment 2015 - How are the world's forests changing? 2nd edition. Rome: FAO.

FAO 2018. The State of the World's Forests 2018 - Forest pathways to sustainable development. Rome: FAO.

FAO and EFI (European Forest Institute) 2018. Making forest concessions in the tropics work to achieve the 2030 Agenda: Voluntary guidelines. FAO Forestry Paper 180. Rome: FAO.

Fearnside, P. M. 2016. Environmental and social impacts of hydroelectric dams in Brazilian Amazonia: Implications for the aluminum industry. World Development 77:48-65.

Ferreira, J., Aragão, L. E. O. C., Barlow, J. et al. 2014. Brazil's environmental leadership at risk. Science 346(6210):706-7.

Gale, T. 2016. Thinking globally about ecotourism impact: The contribution of ecological footprint analysis. In Hill, J. and Gale, T. (eds.) Ecotourism and environmental sustainability. London: Routledge, pp. 49-66.

Hosonuma, N., Herold, M., De Sy, V. et al. 2012. An assessment of deforestation and forest degradation drivers in developing countries. Environmental Research Letters 7(4):044009.

ILO 2017. Information System on International Labour Standards - Ratification of ILO Conventions. International Labour Organization. Available at: www.ilo.org/dyn/normlex/en/ $\mathrm{f}$ ? $\mathrm{p}=1000: 11001::$ NO::: (Accessed 29 December 2018).

ILO 2018a. ILOSTAT - the world's leading source of labour statistics. International Labour Organization. Available at: www.ilo.org/ilostat/faces/ilostat-home/metadata?_adf.ctrlstate=vwps62w1y_57\&_afrLoop=796086079109955\#! (Accessed 29 December 2018).

ILO 2018b. Decent work and the Sustainable Development Goals: A guidebook on SDG labour market indicators. Geneva: ILO, Department of Statistics (STATISTICS).

Jusys, T. 2017. A confirmation of the indirect impact of sugarcane on deforestation in the Amazon. Journal of Land Use Science 12(2-3):125-37.

Lange, G. M., Wodon, Q. and Carey, K. (eds.) 2018. The changing wealth of nations 2018: Building a sustainable future. Washington, DC: World Bank.

Larson A. M., Monterroso, I. and Canturias, P. 2018. Gender and formalization of native communities in the Peruvian Amazon. CIFOR InfoBrief 238. Bogor, Indonesia: CIFOR. 
Larson, A. M. and Soto, F. 2008. Decentralization of natural resource governance regimes. Annual Review of Environment and Resources 33:213-39.

Lebedys, A. and Yanshu, L. 2014. Contribution of the forestry sector to national economies, 19902011. Forest Finance Working Paper 09. Rome: FAO.

Le Blanc, D. 2015. Towards integration at last? The Sustainable Development Goals as a network of targets. Sustainable Development 23(3):176-87.

Lélé, S. M. 1991. Sustainable development: a critical review. World Development 19(6):607-21.

Lewis, W. A. 1954. Economic Development with Limited Supplies of Labour. Manchester School of Social Science 22:139-91.

Macqueen, D. 2008. Supporting small forest enterprises - A cross-sectoral review of best practice. IIED Small and Medium Forestry Enterprise Series No. 23. London: IIED.

Macqueen, D., Bolin, A., Greijmans, M., Grouwels, S. and Humphries, S. 2018. Innovations towards prosperity emerging in locally controlled forest business models and prospects for scaling up. World Development https://doi.org/10.1016/j.worlddev.2018.08.004

Malkamäki, A., D'Amato, D., Hogarth, N. J. et al. 2018. A systematic review of the socioeconomic impacts of large-scale tree plantations, worldwide. Global Environmental Change 53:90-103.

Mawdsley, E. 2015. DFID, the private sector and the re-centring of an economic growth agenda in international development. Global Society 29(3):339-58.

Max-Neef, M., Elizalde, A. and Hopenhayn, M. 1992. Development and human needs. In Elkins, P. and Max-Neef, M. (eds.) Real-Life economics: Understanding wealth creation. London: Routledge, pp. 197-213.

Megevand, C., Mosnier, A., Hourticq, J. et al. C. 2013. Deforestation trends in the Congo Basin: Reconciling economic growth and forest protection. Washington, DC: World Bank.

Miteva, D. A. 2019. The integration of natural capital into development policies. Oxford Review of Economic Policy 35(1):162-81.

Mwitwa, J., German, L., Muimba-Kankolongo, A. and Puntodewo, A. 2012. Governance and sustainability challenges in landscapes shaped by mining: Mining-forestry linkages and impacts in the Copper Belt of Zambia and the DR Congo. Forest Policy and Economics 25:19-30.

O'Rourke, D. and Connolly, S. 2003. Just oil? The distribution of environmental and social impacts of oil production and consumption. Annual Review of Environment and Resources 28(1):587-617.

Porter-Bolland, L., Ellis, E. A., Guariguata, M. R. et al. 2012. Community managed forests and forest protected areas: An assessment of their conservation effectiveness across the tropics. Forest Ecology and Management 268:6-17.

Regmi, K. D. and Walter, P. 2017. Modernisation theory, ecotourism policy, and sustainable development for poor countries of the Global South: perspectives from Nepal. International Journal of Sustainable Development \& World Ecology 24(1):1-14.

Rodgers, G. 2007. Labour market flexibility and decent work. DESA Working Paper 47. New York: United Nations. 
Roemer, M. 1979. Resource-based industrialization in the developing countries: a survey. Journal of Development Economics 6(2):163-202.

Romero, C., Sills, E. O., Guariguata, M. et al. 2017. Evaluation of the impacts of Forest Stewardship Council (FSC) certification of natural forest management in the tropics: A rigorous approach to assessment of a complex conservation intervention. International Forestry Review 19(S2):36-49.

Rostow, W. W. 1959. The stages of economic growth and the problems of peaceful co-existence. Center for International Studies. Cambridge, MA: Massachusetts Institute of Technology.

RRI 2017. Securing community land rights: Priorities and opportunities to advance climate and Sustainable Development Goals. Washington, DC: RRI.

RRI 2018. At a crossroads: Consequential trends in recognition of community-based forest tenure from 2002 to 2017. Washington, DC: RRI.

Schandl, H., Hatfield-Dodds, S., Wiedmann, T. et al. 2016. Decoupling global environmental pressure and economic growth: scenarios for energy use, materials use and carbon emissions. Journal of Cleaner Production 132:45-56.

Schmelzer, M. 2017. History, hegemony, and the contested making of economic growthmanship. In Caradonna, J. L. (ed.) Routledge handbook of the history of sustainability. London: Routledge, pp. 164-86.

Shackleton, C., Shackleton S. and Shanley, P. (eds.) 2011. Non-timber forest products in the global context. Berlin: Springer.

Stoian, D., Donovan, J. and Poole, N. 2009. Unlocking the development potential of community forest enterprises: Findings from a comparative study in Asia, Africa, Latin America, and the United States. Paper presented at the XIII World Forestry Congress held in Buenos Aires on 18-23 October 2009.

Stoian, D., Rodas, A., Butler, M. Monterroso, I. and Hodgdon, B. 2019. The forest concessions in Petén, Guatemala: A systematic analysis of the socio-economic performance of the community enterprises in the Maya Biosphere Reserve. Nairobi: Bioversity International, CIFOR, Rainforest Alliance, World Agroforestry.

Sunderland, T., Achdiawan, R., Angelsen, A. et al. 2014. Challenging perceptions about men, women, and forest product use: A global comparative study. World Development 64:S56-66.

Swamy, L., Drazen, E., Johnson, W. R. and Bukoski, J. J. 2018. The future of tropical forests under the United Nations Sustainable Development Goals. Journal of Sustainable Forestry 37(2):221-56.

Switzer, J. 2001. Armed conflict and natural resources: The case of the minerals sector. London: IIED.

Thornton, J. R., Agnello, R. J. and Link, C. R. 1978. Poverty and economic growth: Trickle down peters out. Economic Inquiry 16(3):385-94.

Tipps, D. C. 1973. Modernization theory and the comparative study of national societies: A critical perspective. Comparative Studies in Society and History 15(2):199-226.

Tomberlin, D., Buongiorno, J., Alegría, J. A., Korhonen, K. and Palo, M. 2001. Timber plantations, timber supply and forest conservation. In Palo, M., Uusivuori, J. and Mery, G. (eds.) World forests, markets and policies. Dordrecht: Springer, pp. 85-96. 
UN 2018. The Sustainable Development Goals Report 2018. New York: United Nations.

UN 2019. Sustainable Development Goals Knowledge Platform. Available at: https:// sustainabledevelopment.un.org/ (Accessed 15 February 2019).

UNCTAD 2018. World Investment Report 2018 - Investment and new industrial policies. New York: UNCTAD.

van der Ven, H., Rothacker, C. and Cashore, B. 2018. Do eco-labels prevent deforestation? Lessons from non-state market driven governance in the soy, palm oil, and cocoa sectors. Global Environmental Change 52:141-51.

Verner, D. and Blunch, N. H. 1999. Sector growth and the dual economy model: Evidence from Cote d'Ivoire, Ghana, and Zimbabwe. Washington, DC: The World Bank.

Vijay, V., Pimm, S. L., Jenkins, C. N. and Smith, S. J. 2016. The impacts of oil palm on recent deforestation and biodiversity loss. PLoS ONE 11(7):e0159668. https://doi.org/10.1371/ journal.pone.0159668.

Weitz, N., Nilsson, M. and Davis, M. 2014. A nexus approach to the post-2015 agenda: Formulating integrated water, energy, and food SDGs. SAIS Review of International Affairs $34(2): 37-50$.

Wily, L. A. 2011. 'The law is to blame': The vulnerable status of common property rights in subSaharan Africa. Development and Change 42(3):733-57.

Winemiller, K. O., McIntyre, P. B., Castello, L. et al. 2016. Balancing hydropower and biodiversity in the Amazon, Congo, and Mekong. Science 351(6269):128-9.

World Bank 2016. World Bank Group Forest Action Plan FY16-20. Washington, DC: World Bank.

World Bank 2017. World Development Indicators: Contribution of natural resources to gross domestic product. Available at: http://wdi.worldbank.org/table/3.14 (Accessed 29 December 2018).

World Bank 2018a. World Development Indicators: Agriculture, forestry, and fishing, value added (\% of GDP). Available at: https://data.worldbank.org/indicator/NV.AGR.TOTL.ZS (Accessed 29 December 2018).

World Bank 2018b. World Development Indicators: Employment in agriculture (\% of total employment) (modeled ILO estimate). Available at: https://data.worldbank.org/indicator/ SL.AGR.EMPL.ZS (Accessed 29 December 2018).

World Bank 2018c. Implementing the 2020 Agenda - 2018 Update. Washington, DC: World Bank. WTTC (World Travel \& Tourism Council) 2018. Travel \& Tourism Economic Impact 2017: World. London: WTTC.

Yakovleva, N. 2017. Corporate social responsibility in the mining industries. London: Routledge. 